\title{
Milli Eğitim Bakanlığ1 Taşra Teşkilatı Yöneticileri: Milli Eğitim Müdürleri Üzerine Nitel Bir Çalışma
}

\author{
Bilgen KIRAL ${ }^{1}$
}

Öz

Araştırma milli eğitim müdürlerinin kim olduğunu, görevlerini, rollerini, nasıl olmaları gerektiğini öğretmen adaylarının bakış açısına göre tespit etmek amacıyla yapılmıştır. Yapılan araştırma nitel araştırma olup; fenomenoloji deseninde yürütülmüştür. Araştırma bir devlet üniversitesinin eğitim fakültesinde, 2019-2020 akademik y1lı ikinci döneminde araştırmaya katılmaya gönüllü 106 öğrenci ile yürütülmüştür. Katıllmcılar, ölçüt örnekleme yöntemine göre seçilen, 4. sınıfta öğrenim gören farklı branşlardaki öğrencilerdir. Araştırma kapsamında öncelikle ilgili fakülteden resmi izin ve etik kurul izni alınarak araştırmaya başlanmıştır. Araştırmada milli eğitim müdürlerinin yöneticilik görevi üstlenen kişi olduğu en çok tekrarlanan kategoridir. Öğrencilere milli eğitim müdürünün nasıl olduğu sorulduğunda diksiyonu iyi, takım elbiseli, resmi, soğuk görünüşlü olduğuna ilişkin cevaplar verilmiştir. Öğrencilere milli eğitim müdürlerinin hangi özelliklere sahip olması gerektiği sorulduğunda ise öğrencilerin verdikleri cevaplar doğrultusunda dört temel kategori oluşturulmuştur. Bunlar; eğitimsel, kişilik, iletişimsel ve etik özellikleridir. Milli eğitim müdürlerinin lisansüstü düzeyde (yüksek lisans ve doktora) eğitimli olması gerektiği en fazla olması istenen özelliktir. Kişilik bakımından örnek olmaları gerektiği, yeniliğe, değişime açık olmaları gerektiği de ayrıca vurgulanmıştır. Bunların dışında milli eğitim müdürlerinin siyaset yapmamaları, adaletli olmaları gerektiği de ifade edilmiştir. Ayrıca düzgün ve etkili konuşma en çok tekrarlanan ifadelerdendir. Milli eğitim müdürlerinin hangi rollerinin olduğu sorulduğunda ise yönetici, anne-baba, öğretmen, denetleyici gibi rolleri olduğu ifade edilmiştir.

Anahtar Kelimeler: Milli eğitim müdürü, Görev, Sorumluluk, Rol, Özellik

\section{Provincial Organization Administrators of the Ministry of National Education: A Qualitative Study on Directors of National Education}

\section{Abstract}

The research was carried out to determine according to the candidate teachers' opinions who the superintendents of national education, their duties, roles, and how they should be. The research conducted as a qualitative research, and phenomenology design. The research was carried out with 106 students who volunteered to participate in the research in the education faculty of a public university in the second semester of the 2019-2020 academic year. Participants are in the 4th grade students in different branches that are selected according to the criterion sampling method. Within the scope of the research, the research has been started by obtaining official permission and ethics committee permission from the related faculty. It is the most repeated category in the research where the superintendents of the national education are the people who assume the management duties. When the students were asked how the head of the education they saw, they were given answers regarding that they had good speaking, suits, formal and cool looks. When asked about the characteristics of the superintendents, four basic categories were created in line with the answers given by the students. They are educational, personality, communicative and ethical characteristics. It is the most desired characteristics that superintendents should be trained at postgraduate level (master and $\mathrm{PhD}$ ). It was also emphasized that they should be model in terms of personality, open to innovation and change. Apart from these, it was also stated that the superintendents of national education should not do politics in their speech and that they should be fair. In addition, kind and effective speech is one of the most repeated expressions. When asked which roles of superintendents are, it is stated that they have roles such as manager, parent, teacher, supervisor.

Key Words: Superintendent of national education, Duty, Responsibility, Role, Characteristic

Atıf İçin / Please Cite As:

Kıral, B. (2021). Milli Eğitim Bakanlığı taşra teşkilatı yöneticileri: Milli eğitim müdürleri üzerine nitel bir çalışma. Manas Sosyal Araștirmalar Dergisi, 10(1), 98-122.

Geliş Tarihi / Received Date: 15.07.2020

Kabul Tarihi / Accepted Date: 05.11.2020

\footnotetext{
${ }^{1}$ Doç. Dr. - Aydın Adnan Menderes Üniversitesi Eğitim Fakültesi, bilgen.kiral@adu.edu.tr 


\section{Giriş}

Eğitim sistemlerinin şekillenmesinde rol oynayan en önemli yap1 taşları öncelikle karar vericiler, ardından uygulayıcılardır. Karar vericilerin aldığı kararlar, uygulayıcılar tarafindan hayata geçirilmektedir. Hem karar vericiler hem de uygulayıcılar arasında yönetim kademeleri ve hiyerarşik bir yapılanma mevcuttur. Bunun sebebi Türk eğitim sisteminin merkezi bir yönetim yapısına sahip olmasıdır. Merkezdeki yönetim Milli Eğitim Bakanlığı (MEB) adını almaktadır. Eğitimle ilgili kararların alındı̆̆ı, politikaların belirlendiği MEB merkez, taşra ve yurt dışı teşkilatı olarak üçe ayrılmaktadır. Bu teşkilatta merkez teşkilatı kararları alırken; taşra ve yurtdışı teşkilatının uygulayıcı konumda olduğu bilinmektedir. Özellikle taşra teşkilatı bu yapının en önemli parçasıdır. Taşra teşkilatı il ve ilçe milli eğitim müdürlükleri ile okullar ve ilgili kurumlardan oluşmaktadır. Milli Eğitim Bakanlığı taşra teşkilatının temelleri 22.03 .1926 tarih ve 789 sayılı Maarif Teşkilatına Dair Kanun'un 20. maddesi ile atılmıştır. İlgili maddede "Türkiye maarif teşkilâtı itibar ile montıkalara ayrnlmıștr. Bir veya bir kaş vilâyetten teşekkeül eden her montıkada bir maarif emini bulunur. Her vilâyette aynca bir maarif müdürü veya memuru dabi vardır." ifadeleri yer almaktadır. Buradan anlaşılan o ki Türkiye Cumhuriyeti’nin kurulmasının ardından Milli Eğitim Bakanlığı'nda bir yapılanmaya gidildiği, bununla birlikte il ve ilçe milli eğitim müdürlüklerinin resmi olarak kurulmasının da bu kanunla şekillendiği söylenebilir.

Zaman içerisinde taşra teşkilatının yapısında çeşitli değişimler yapılmıştır. Bugünkü yapılanmanın temelleri ise 14.09.2011 tarihli 652 sayılı Milli Eğitim Bakanlığı'nın Teșkilat ve Görevleri Hakkında Kanun Hükmünde Kararname (KHK) ile atılmıştır. İlgili KHK'nin 3. maddesi ile bakanllğın merkez, taşra ve yurtdışı teşkilatı olarak ayrıldığı belirtilmektedir. 30. madde ise taşra teşkilatı ile ilgilidir. Milli Eğitim Bakanlığı teşkilat yapısı ile ilgili en son düzenlemeler ise 2018 yılında çıarıllan Cumhurbaşkanlı̆̆ 1 nolu Kararnamesi (CK) ile yapılmıştır. Bu kararnamenin 302. maddesi MEB'in merkez, taşra ve yurtdışı teşkilatı olarak ayrıldığını; 327. maddesi ise doğrudan taşra teşkilatının yapılanmasını ilgilendirmektedir. $\mathrm{Bu}$ maddeye göre bakanlığın, taşra teşkilatı kurmaya yetkili olduğu; her ilde ve ilçede bir milli eğitim müdürlüğ̈̈ kurulacağg; ilçe milli eğitim müdürlüklerinin görev ve hizmetlerini yerine getirirken il milli eğitim müdürlüklerine karşı da sorumlu olacağı belirtilmektedir. Ayrıca il ve ilçelerin sosyal ve ekonomik gelişme durumları, nüfusları ve öğrenci sayıları göz önünde bulundurularak, bu müdürlüklerin farklı tip ve statülerde kurulabileceği, bunlara farklı yetkiler verilebileceği; iş durumuna ve ihtiyaca göre milli eğitim müdürlüklerine bağlı olarak ayrı il ve ilçe birimlerinin de kurulabileceği ifade edilmektedir (CK 1, 2018, 327. Md.). Taşra teşkilatının günümüze ait yapılanması aşağıda Şekil 1'de verilmiştir.

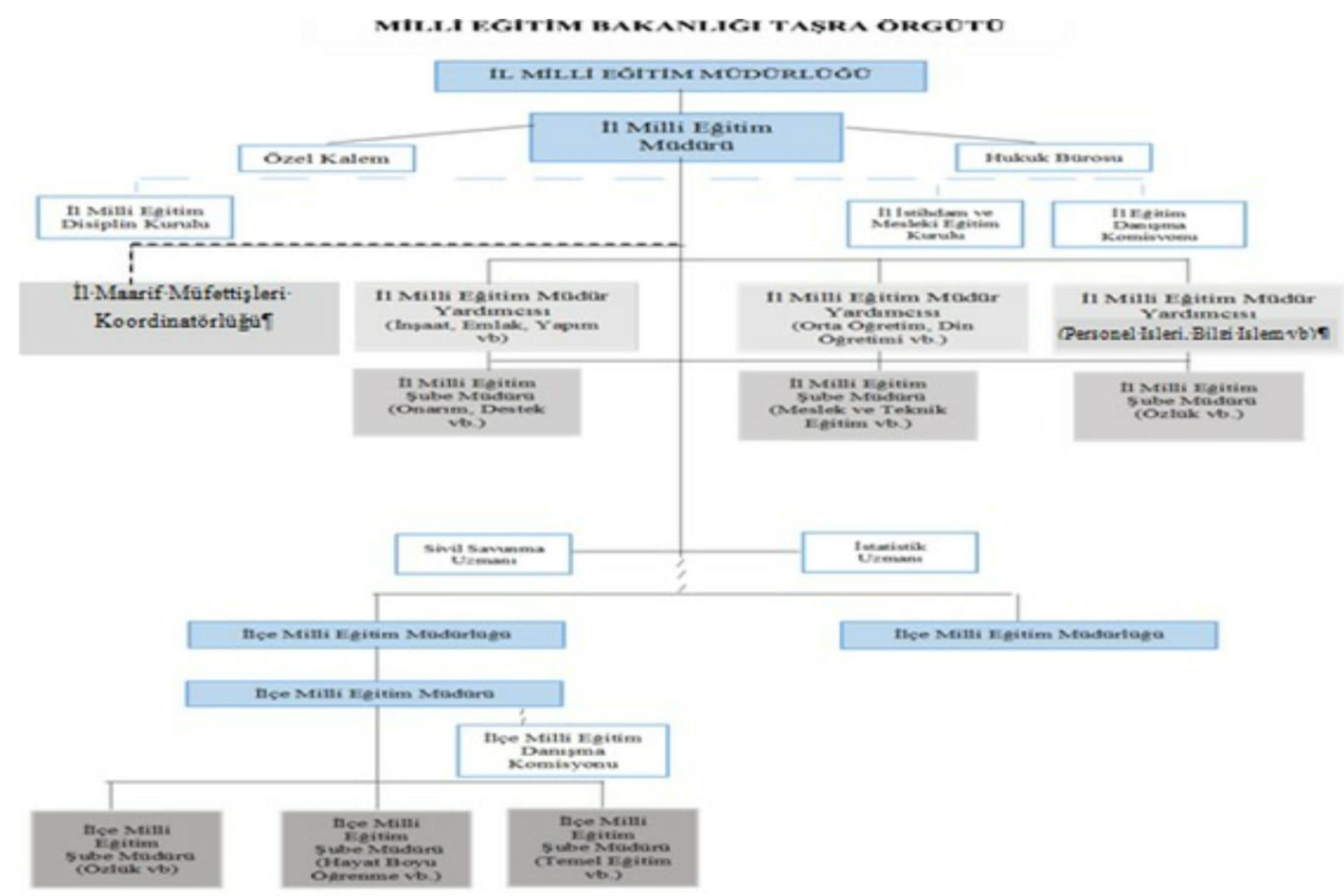

Şekil 1. Milli Ë̆̈itim Bakanlğ Taşra Teşkilatı (Kaynak: E. Kıral'dan (2019) alınmıştır) 
Şekil 1'de görüldüğü gibi taşra teşkilatı il ve ilçe milli eğitim müdürlükleri ile okullar ve kurumlardan oluşmaktadır. İl milli eğitim müdürlükleri; il milli eğitim müdürü, müdür yardımcıları, şube müdürleri olarak; ilçe milli eğitim müdürlükleri ise ilçe milli eğitim müdürü ve şube müdürleri olarak yönetim kademelerine ayrllmıştır. Tüm birimler kendi üstünde yer alan yönetim kademesine ve milli eğitim müdürüne karşı sorumludur.

18 Temmuz 2020 tarih ve 31189 sayılı MEB Personelinin Görevde Yükselme, Unvan Değiş̧ikliği ve Yer Değiştirme Suretiyle Atanması Hakkında Yönetmelikte Değişiklik Yapılmasına dair Yönetmeliğin 23. maddesinde ilçe milli eğitim müdürlügü kadrosuna atanmak için "yažl veya yaz̨l ve sözlü sinav kazanarak atanmıs olmalar şartylla; eğitim kurumu müdürlü̈ü görevinde en az dört ynl, şube müdürü kadrosunda en az iki ynl ya da bu fikrada saynlan görev ve kadrolarda toplam dört yuldan az olmamak üzere asaleten görev yapmis ve ögretmenlikte adaylhğa kaldmrlmıs olmak şartlar aranır.” denilmektedir. Bu yönetmelikle Milli Eğitim Bakanlığı merkez ve taşra teşkilatına ait yönetici kadrolarına atanacaklar hakkındaki nitelikler, esas ve usuller diğer yönetmelikler de göz önüne alınarak tekrar düzenlenmiştir. Cumhurbaşkanlı̆̆1 1 nolu Kararnamesi’nin (CK) 327. maddesinde il müdürü atamalarına ilişkin özel bir düzenlemeye yer verilmediği; sadece ilçe milli eğitim müdürlüğüne ataması için bir takım şartların getirildiği görülmektedir. Yeni düzenlemede (CK 1, 2018) şef ve şube müdürleri için görevde yükselme eğitimi alma ve bu eğitim sonunda başarılı olma şartı aranmakta; ilçe milli eğitim müdürü, il milli eğitim müdür yardımcısı, il milli eğitim müdürü ve daha üst kadrolar için ise yönetim görevinde bulunmuş olma şartı getirilmektedir. Aslında il veya ilçe milli eğitim müdürü olmak için bilinen ilk şartın devlet memuru olmak ve devlet memurlarının sahip olduğu şartlara sahip olmak olduğu söylenebilir (Kaya, 1999). Milli Eğitim Bakanlığ1 Yönetici Atama ve Görevde Yükselme Yönetmeliği’nin (12.10.2013/28793) bazı maddeleri "çesitli yönetmeliklerle değģsilkliğe ü̆ramıs̆" olsa da yönetim kademelerinde bir değişiklik yapılmamışır. Bu yönetmeliğe göre yönetim kademeleri aşağıdaki şekilde tespit edilmiştir. Buna göre yönetim kademeleri: Birinci kademe şef; ikinci kademe ilçe ve il milli eğitim müdürlüğünde şube müdürü; üçüncü kademe ilçe milli eğitim müdürü, il milli eğitim müdür yardımcıs1, bakanlık şube müdürü; dördüncï kademe il milli eğitim müdürü, daire başkanı (bağımlı), daire başkanı (bağımsız), genel müdür yardımcısı, hukuk müşaviri, genel müdür, araştırma planlama ve koordinasyon kurulu başkanı, teftiş kurulu başkanı, Talim ve Terbiye Kurulu Başkanı, müsteşar yardımcısı olarak ifade edilmektedir. Yönetici olarak atanacaklarda aranacak genel şartlar şunlardır: Yükseköğrenimli olmak, dört veya daha yukarı derecelerdeki kadrolara atanacaklar için 657 sayll Kanun'un 68'inci maddesi (B) bendinde belirtilen sürelerde hizmeti bulunmak, son yila ait sicil notu olumlu olmak kaydıyla son üç yıllık sicil notu ortalaması en az iyi olmak, dördüncü kademe yöneticilik görevlerine atanacaklarda aylıktan kesme veya maaş kesimi cezası dâhil daha ağır bir disiplin cezası almamış olmak şeklindedir. Bu sayılan hükümlerin dışında herhangi bir sınav veya benzeri bir şart aranmadığı görülmektedir.

\section{Milli Eğitim Müdürlerinin Görev ve Sorumlulukları}

İl ve ilçe milli eğitim müdürleri, Milli Eğitim Bakanlı̆̆’’nın temsilcileri olarak görev yapmaktadırlar. İl ve ilçelerdeki resmi ve özel eğitim kurumlarının işleyişini denetlemek, bunların faaliyetlerinin bakanlık tarafindan oluşturulan politikalara uygunluğunu kontrol etmek ve bu kurumları bakanlığın hedefleri doğrultusunda çalışmaları için gerekli yönlendirmeleri yapmakla görevlidirler (Kaya, 1999). Başaran (1988; 1991) milli eğitim müdürlüklerini hiyerarşik bir sistem olan bakanlı̆̆ın, arac1 üst sistemi olarak ifade etmekte ve kendilerine bağlı olan sistemlerin üretimlerini etkileyecek yönetsel kararlarda söz sahibi olduklarını ifade etmektedir. Cafoğlu (1996) ise milli eğitim müdürlüklerinin stratejik olarak önemli olduklarını ifade etmektedir. Şöyle ki yönetim süreçlerinin etkin kullanılması ile bakanlıktan gelen direktifler doğrultusunda il ve ilçeler için üst düzey yönetsel kararlar alınıp uygulanmaktadır. İl ve ilçe milli eğitim müdürlüklerinin görevleri eğitim kurumlarının etkili ve verimli işlemesi, toplumsal gelişmenin eğitim kurumları vasitasıyla sağlanması olarak söylenebilir.

Yukarıdaki sayllanlardan başka MEB İl ve İlçe milli Eğitim Müdürlükleri Yönetmeliğ̣’’nde milli eğitim müdürlerinin görevleri ile ilgili çeşitli maddeler bulunmaktadır. Milli eğitim müdürleri, "Bakanliğm eğitim politikalar ve stratejik, planlarm, mev₹uat ve programlar doğrultusunda yönetmek, yönlendirmek, denetlemek ve koordine ederek etkin ve verimli bir şekilde yerine getirmek ile görevli ve sorumludurlar. Milli eğitim müdürleri, bu görevlerini il ve ilçe yöneticileri arasmda yapacaklar iş bölümü çerçevesinde yürütür" (Md. 6/1) ifadesi yer almakla birlikte bu görev ylllar içerisinde yenilenen yönetmeliklerde de yer almıştır. En güncel yönetmelik olan 19 Temmuz 2020 yönetmeliğinde de bu maddede de değişiklik görülmemiştir.

Milli eğitim müdürlerinin; temel eğitim, ortaöğretim, mesleki ve teknik eğitim, din öğretimi, özel eğitim ve rehberlik, hayat boyu öğrenme, özel öğretim kurumları, bilgi işlem ve eğitim teknolojileri, ölçme, 
değerlendirme ve sınav, yükseköğretim ve yurt dışı eğitim, strateji geliştirme, insan kaynakları yönetimi, destek, inşaat ve emlak ile ilgili iş ve işlemleri milli eğitim müdürüne bağlı birimler ve bürolar vasıtasıyla yürütmek gibi görevleri vardır (2018/Md. 8). Bunlara yönelik görevleri Şekil 2'de araştırmacı tarafindan oluşturulan şekilde verilmiştir.

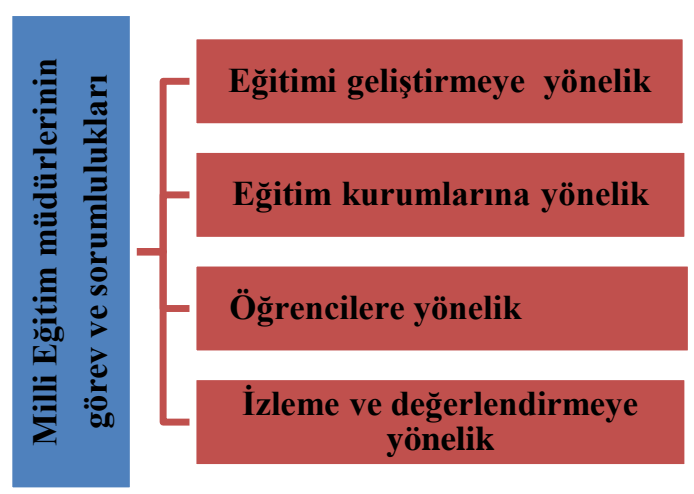

\section{Şekil 2. Milli Eğitim Müdürlerinin Görev ve Sorumluluklar}

Şekil 2'de görüldüğü gibi milli eğitim müdürlerinin görev ve sorumlulukları dört başlı altında incelenmektedir. Bunlar; eğitimi geliştirmeye, eğitim kurumlarına, öğrencilere ve izleme ve değerlendirmeye yönelik görevler ve bunlara bağlı sorumluluklar başlıklarında toplanmaktadır (2018/Md. 9). Aşağıda milli eğitim müdürlerinin sayılan bu görevleri ve görevlerine ilişkin sorumlulukları açıklanmıştır.

Eğitimi gelistirmeye yönelik görevler: Eğitim-öğretim programlarının uygulanmasını sağlamak, ders kitapları, öğretim materyalleri ve eğitim araç-gereçlerine ilişkin işlemleri yürütmek, firsat eşitliğini sağlamak, eğitime erişimi teşvik edecek ve artıracak çalışmalar yapmak, eğitim hizmetlerinin yürütülmesinde verimliliği sağlamak, eğitime ilişkin projeler geliştirmek, uygulamak ve sonuçlarından yararlanmak, kamu ve özel sektör eğitim paydaşlarıyla işbirliği içinde gerekli iş ve işlemleri yürütmek, eğitim hizmetlerinin geliştirilmesini sağlamak olarak sayılabilir (2018/Md.9).

Ë̆itim kurumlarna yönelik görevler: Eğitim ortamlarının fiziki imkânlarını geliştirmek, resmi eğitim kurumlarının açılması, kapatılması ve dönüştürülmesi işlemlerini yürütmek, öğrencilere barınma hizmeti sunulan eğitim kurumlarında bu hizmeti yürütmek, eğitim kurumları arasında işbirliğini sağlamak, eğitim kurumlarının idari kapasite ve yönetim kalitesinin geliştirilmesini sağlamak, eğitim kurumları arasındaki kalite ve sayısal farklılıkları giderecek tedbirler almak, kutlama veya anma gün ve haftalarının programlarını hazırlamak, uygulatmak olarak say1labilir. (2018/Md.9)

Öğrencilere yönelik görevler: Rehberlik ve yöneltme/yönlendirme çalısmalarını planlamak, yürütülmesini sağlamak, öğrencilerin kayıt-kabul, nakil, kontenjan, ödül, disiplin ve başarı değerlendirme iş ve işlemlerinin yürütülmesini sağlamak, öğrencilerin yatıllık ve burslulukla ilgili işlemlerini yürütmek, öğrencilerin ulusal ve uluslararası sosyal, kültürel, sportif ve izcilik etkinliklerine ilişkin iş ve işlemlerini yürütmek, öğrencilerin okul başarısını artıracak çalışmalar yapmak, yaptırmak, öğrencilerin eğitim sistemi dışında bırakılmamasını sağlayacak tedbirleri almak, yurtdışında eğitim alan öğrencilerle ilgili iş ve işlemleri yürütmek, öğrencilerin okul dış1 etkinliklerine ilişkin çalışmalar yapmak, yaptırmak, sporcu öğrencilere yönelik hizmetleri planlamak, yürütülmesini sağlamak, okul sağlık hizmetlerinin yürütülmesini sağlamak, eğitim, danışmanlık hizmetlerinin yazışma ve koordinesinin yürütülmesini sağlamak olarak sayılabilir (2018/Md.9).

İleme ve değerlendirmeye yönelik görevler: Eğ̈tim kurumu yöneticilerinin performanslarn iəlemek ve değerlendirmek, eğitim öğretim programlarının uygulanmasını izlemek ve değerlendirmek, öğretim materyallerinin kullanımını izlemek ve değerlendirmek, öğretmen yeterliliklerini izlemek ve değerlendirmek olarak sayılabilir (2018/Md.9).

Milli eğitim müdürleri görevlerini ve görevlerine ilişkin sorumluluklarını yerine getirirken Milli Eğitim Bakanlığ1 tarafindan oluşturulan yasal metinler ve politikalar doğrultusunda karar almakta, yapılan faaliyetleri planlamakta, örgütlemekte, eşgüdümlemekte, etkileme yollarını ve iletişim kanallarını etkin kullanmakta, sonunda da yapılan faaliyetleri denetlemekte ve değerlendirmekte oldukları söylenebilir. Amaç var olan sistemin devamını en iyi şekilde sağlamanın yanında, gelişim için gerekli adımları atmaktır. Bu sebeple de görevlerinin yanı sıra bir takım roller de oynamak durumundadırlar. 


\section{Milli Eğitim Müdürlerinin Rolleri}

Milli eğitim müdürleri, sorumlu oldukları bölgedeki akademik başarının artırılması için, yukardan aşağıya çeşitli stratejiler uygulayarak, okullara ve kurumlara çeşitli baskılar yapmaktadırlar (Kowalski, 2005, ss. 107-111). Bu sebeple de çeşitli roller üstlenmektedirler. Milli eğitim müdürlerinin rollerini Callahan (1966, ss. 143-210) uzman-öğretmen, örgüt yöneticisi, demokratik lider ve toplum bilimci rolü olarak dörde ayırmışır. Beşinci rol ise Kowalski (2005) tarafindan tanımlanmıştır. Bu beşinci rol, iletişimci rolüdür. Callahan’a (1966) göre milli müdürleri 1850’li yıllardan 1900'lü y1llara kadar uzman-öğretmen; 1900’lü y1llardan 1930'lu yıllara kadar örgüt yöneticisi, 1930'dan 1950’lere kadar demokratik lider, 1950’lerden 1970'lere kadar toplum bilimci, 1970’lerden günümüze kadar ise iletişimci rolünü üstlenmişlerdir (Kowalski, 2005, ss. 101-117). Bunlara ilaveten son rol olarak takım liderliği rolü de çeşitli araştırmacılar (Capella, 1987; Millar ve Rogers, 1976; Reitzz, 1987 gibi) tarafindan kullanılmaktadır. Her bir rolün özellikleri ayrı ayrı tarif edilmesine ve ilgili yıllarda baskın rol olarak algılanmış olmasına rağmen, milli eğitim müdürleri bugün genellikle iki veya daha fazla rolü aynı anda uygulayabilmektedirler (Björk Kowalski, ve Browne-Ferrigno, 2014). Adı geçen sinıflamalarda yer alan tüm roller araştırmacı tarafindan oluşturulmuş olan Şekil 3’te verilmiştir.

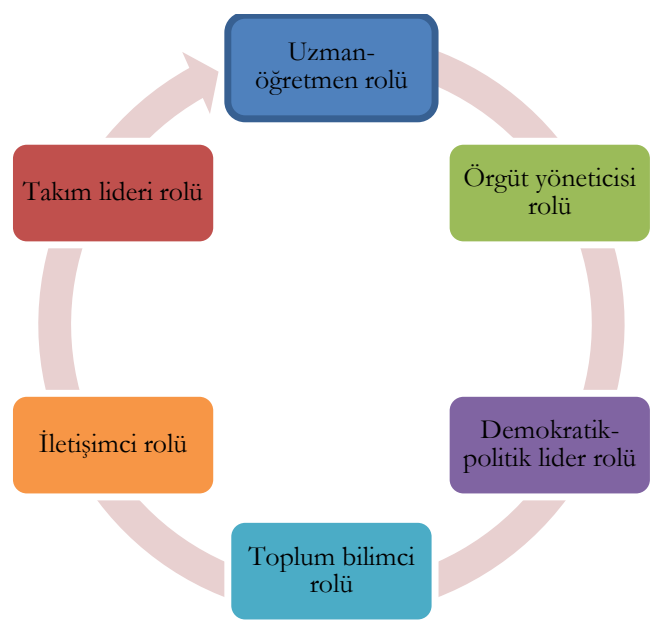

\section{Şekil 3. Milli Ĕ̈itim Müdürlerinin Rolleri}

Şekil 3’te de görüldüğü gibi milli eğitim müdürlerinin alan yazında altı temel rolü bulunmaktadır. Bunlar uzman öğretmen, örgüt yöneticisi, demokratik-politik lider, toplum bilimci, iletişimci ve takım lideri rolüdür. Milli eğitim müdürleri geçmişte belli rolleri üstlenmiş olsalar bile günümüzde bu rollerin bir kaçını veya tümünü birlikte üstlenebilmektedirler. Bu sebeple bunlar aslında bir bütün oluşturmaktadır denilebilir. Milli eğitim müdürleri ile ilgili sayılan rollere ilişkin çalışmalar özellikle yabancı alan yazında ve yabanc1 araştırmacılar (Björk vd., 2014; Callahan, 1966; Capella, 1987; Kowalski, 2005; Millar ve Rogers, 1976; Reitzz, 1987 gibi) tarafından yapılmışır. Türkçe alan yazında ve Türk araştırmacılar tarafindan milli eğitim müdürlerinin rollerine ilişkin özel olarak yapılmış bir çalışmaya henüz rastlanılmamış olup; verilen bilgiler yabancı alan yazına bağlı kalınarak aşağıda açıklanmıştır.

U₹man-ögretmen rolü (Teacher-scholar role): 20. yüzylldan önce milli eğitim müdürleri uzman öğretmen olarak hizmet vermişler; ancak 20. yüzyılın başlarında çalışmaları zorunlu devlet müfredatının ve öğretmenlerin denetimi üzerine yoğunlaşmıştır. İlerleyen yıllarda bu rolleri artan ihtiyaçlar, kapasitenin değişmesi, demografik değişimler, artan sanayileşme, kentleşme ve göç sebebiyle bir takım değişimlere uğramıştır. Burada çocukların var olan bu yeni kültüre uyum sağlamaları için rollerinde bir takım yenileşmeler yapmak zorunda kalmışlardır. Bu noktada, öğretimsel gelişme ve uzman-öğretmen rollerini diğer eğitimcilerden farklı bir şekilde yürürlüğe koymalarına rağmen, milli eğitim müdürleri istikrarlı çalışmanın önemini her firsatta vurgulamışlardır (Callahan, 1962, ss. 188-196). Bu bağlamda öğretim liderleri olarak vizyoner liderlik sağlamak, öğretmenlerin ve öğrencilerin beklentilerini yerine getirmek, uzun vadeli planlama ve bütçeleme yapmak, personelin performansını değerlendirmek ve bölge genelindeki iyileştirmeler üzerinde yoğunlaşmak ve öğrencinin akademik başarısını artırmak yönünde rolleri olmuştur (Kowalski ve Björk, 2005, ss. 73-96). Kisacası milli eğitim müdürlerinin bu rolü; eğitimle ilgili her bilgiye hâkim, hem öğrenen hem öğreten kişi olarak ifade edilebilir.

Örgüt yöneticisi rolü (Organizational-manager role): 1800'lerin sonlarında, okul-bölge kurullarının, büyük ve karmaşık eğitim örgütlerinin yönetimi konusundaki endişeleri artmıştır. Çünkü varolan yöneticilerin bilgi 
ve becerilerini yönetme konusunda yeterli olmadığı inancı oluşmuştur (Callahan, 1962, ss. 188-196). Cuban (1976) çeşitli araştırma ve incelemelerde bulunmuş, bunun sonucunda milli eğitim müdürü ve okul müdürlerinin rollerinin değişmesi gerektiği sonucuna varmış, bu da eğitim camiasında tartışlan bir konu haline gelmiştir (Kowalski, 1999, ss. 319-322). Franklin Bobbitt, Ellwood Cubberly ve George Sprayer gibi önde gelen eğitim araştırmacıları, milli eğitim müdürlerinin ve diğer eğitim liderlerinin bir takım iş ve yönetim ilkelerini benimsemesi ve rollerinin değişmesi gerektiği görüşünü desteklemişlerdir (Cronin, 1973, ss. 20-25). Diğer araştırmacılar (George Counts gibi), örgütsel yönetim uygulamalarını dikkate aldığı için (Björk ve Gurley, 2005), okullarla ve kurumsal yönetim kurulu yetkilileri ile aralarında uyumsuzluklar meydana gelmiştir. Bu araştırmacı ve ekibinin görüşleri halkın temel değerleriyle de çelişmiş (Van Til, 1971, ss. 9-17); buna rağmen, okul kurulları örgütsel yönetim modellerini benimsemiş (Browne-Ferrigno ve Glass, 2005) ve milli eğitim müdürlerinin günlük yönetimde ele almaları gereken sorumlulukları buna göre şekillendirmiştir (Örneğin bütçeleme ve personel denetimi, örgüt yönetimi, halkla ilişkiler gibi). Her ne kadar bunlar milli eğitim müdürlerinin yönetim rolü çalışmalarının temel bir yönü ise (Kowalski ve Glass, 2002) de öğretim lideri olarak rollerinin güncellenmesi gerektiği de savunulmuştur (Kowalski vd., 2011, s. 17-24). Kisacası milli eğitim müdürlerinin bu rolü hem bizzat yönettikleri örgütün, hem de eğitim kurumu olan okulların müdürleri ile birlikte örgüt yöneticisi konumunda olmaları şeklinde ifade edilebilir.

Demokratik-politike lider rolü (Democratic-political leader role): Milli eğitim müdürlerinin çalışmalarının ayrılmaz bir parçası devlet işlerinin devam ettirilmesidir. Siyasi karar alma süreçleri ve bölge düzeyinde uygulamalar da rollerinin bir parçasıdır (Björk ve Lindle, 2001). Bu çabaların niteliği ve kapsamı, eğitim için kamu desteğinin alınması, yeterli bütçe ödenekleri için devlet yasama organlarına lobi yapılması, okul kurullarıyla etkileşime girilmesi, bütçe grubu taleplerine cevap verilmesi, tartışmalı kamu politikasının sözcüsü olarak hizmet vermeyi içermektedir. Örgütsel sorunları çözmek ve personelin yer değişim girişimleri de buna dâhil edilebilir (Björk, Kowalski ve Browne-Ferrigno, 2014, s. 17-38).

Milli eğitim müdürleri, çıkar grubu siyasetindeki artışı, siyasi baskıların ve bunların üzerlerindeki yansımalarının kendilerini farklı şekillerde nasıl etkilediğinin bilincinde olarak çalışmalarını yürütmektedirler (Kowalski vd., 2011, s. 17-24). Küçük veya kırsal alanda hizmet veren yöneticiler bu siyasi etkilerin bir sonucu olarak "gruplar kaynaşttrmak, yaşam boyu bizmet vermek ve yapulanlarda yayginllk sağlamak" gibi görevleri üstlenmişlerdir (Lambkin, 2006, s. 19). Bunlar, karar alma süreçlerini etkilemekte ve onların kişisel, politik ve stratejik davranmalarını gerektirebilmektedir (Glass, Björk ve Brunner, 2000, s. 40). Siyasi rollerini yürürlüğe koymalarına rağmen, genellikle bölge büyüklüğüne göre siyasi rollerin mahiyeti değişebilmektedir (Kowalski vd., 2011, s. 17-24). Milli eğitim müdürleri; topluluğun çoğunluğunun katılımını ve kamuoyunu dinlemeyi, demokratik bir toplumun anahtar rolü olarak görmektedirler (Kirst ve Wirt, 2009). Yöneticilerin çoğunluğu okul yönetim kurulu üyeleriyle (mikro politika) ilişkilerini, karşılaştıkları en önemli zorluklardan biri olarak görmektedirler (Kowalski vd., 2011; Björk ve Gurley, 2005). Milli eğitim müdürlerinin yerel düzeyde sistematik gelişimi sağlamak için çeşitli paydaşlarla birlikte çalışmaları, siyasi etkiye sahip olmaları, yöneticiler için olduğu kadar toplumun refahı için de önemlidir (Levin, 1999). Milli eğitim müdürlerinin bu rolü demokratik davranışlar sergileyerek yönettikleri eğitim örgütlerinin iyiliği için tüm politik örgütlerle olumlu ilişki içerisine girmeleri şeklinde söylenebilir.

Toplum bilimci rolü (Social-scientist role): Uygulamacı toplum bilimci olarak milli eğitim müdürleri ulusun sosyal, ekonomik ve siyasal yaşamındaki değişikliklerinde öncü olmak, değişimlerin kamu okullarındaki eğitimi nasıl etkilediğini gözlemleyerek ona uygun bir bilim insanı gibi çeşitli politikalar geliştirmek gibi bir rolleri bulunmaktadır. 1961 yılında W. K. Kellogg Vakfı yaptığı araştırmalarda milli eğitim müdürlerinin, sosyal bilimlerin çoğunu içeren disiplinlerarası bir duyarllık göstermeleri gerektiği sonucuna ulaşmıştır. Bunun için toplumda yer alan devlet okullarında stratejik değişiklikleri yapmak için milli eğitim müdürlerinin yetkili olması gerektiğini, değişiklik yapabilecek en iyi konumdaki kişilerin milli eğitim müdürleri olduğunu açıklamıştır (Callahan, 1966, s. 222).

Callahan (1966, s. 212-216) sosyal bilim araştırma bulgularının halk eğitimi üzerinde derin etkileri olduğunu gözlemleyerek, milli eğitim müdürlerinin araştırma bulguları doğrultusunda sorun çözme konusunda katı olmamaları gerektiğini ifade etmiştir. Ayrıca kamu okullarında sorun çözerken milli eğitim müdürlerinin, daha adil ve demokratik davranmaları, topluma katkıda bulunmak için olaylara geniş perspektiften bakmaları gerektiğini de ifade etmektedir. Milli eğitim müdürlerinin öğrenciler, öğretmenler ve eğitimle ilgili bilgi toplanırken araştırma yapmalı, bilgiye, veriye, kanıta ve performansa dayalı olarak davranması gerekmektedir (Goldring ve Greenfield, 2002). Toplanan veriler sonucunda okulların geliştirilmesine katkıda bulunacak, öğrenci-öğretmen, yönetici ve toplumun ihtiyaçlarını karşılayacak 
bilinçli kararlar ancak araştırma sonuçlarına göre verilebilir (Starratt, 1991, s. 185-202). Veriye dayanmayan çalısmalar sosyal adaletsizliklere, kalıcı değil geçici çözümlere yol açabilir (Fusarelli ve Fusarelli, 2005, s. 187-206). O sebeple milli eğitim müdürleri öncelikle iyi bir araştırmac1, toplum bilimci, sosyal-bilim insanı olarak olaylara bakmalı, gözlemeli, veriye ve araştırmaya dayalı olarak sorunları çözümlemeli, gelişime katkıda bulunmasının ancak bu yolla olduğu söylenebilir.

İletişimci rolü (Communicator role): Thayer (1961, s. 4) örgütlerde iletişim stillerini yukardan aşağıya, şahsi olmayan türde ve resmi, bilgi verme, emir verme, yönlendirme, değerlendirme ve etkileme amaçlı olarak yapıldığını ifade etmiştir. İlerleyen yıllarda sosyal, ekonomik ve politik değişiklikler, iletişim stillerinde de değişikliğe yol açmıştır. Aşağıdan yukarıya, çapraz vb. iletişim stilleri de gündeme gelmiştir. Bazı araştırmalar (Kowalski, 2001; Kowalski vd. 2011) yukarıdan aşağıya aşırı formal ve sert iletişim modelinin, yöneticilerin çalışanlarına yönelik negatif algılarının; çalışanların moralleri, iş tatmini ve örgüte bağlllıkları ile örgütsel verimliliklerini olumsuz etkilediği ve örgütte zararlı bir etkiye sahip olduğu sonucuna ulaşmıştır. $\mathrm{Bu}$ durum sadece çalışanlar için değil, okul toplumunun doğal üyeleri olan veli ve ebeveynler için de geçerlidir (Björk, Kowalski ve Browne-Ferrigno, 2014, s. 17-38).

Gönüllü olarak toplum ve ebeveynlerin okula katılımı, işbirliği düzeyinin artması ise başarıyı artırmaktadır. Bu katılım çalısmaları milli eğitim müdürlerinin desteği ve izin vermeleri sonucu meydana gelmektedir (Björk, 2001, s. 286-309). Schlechty (1997, s. 134) sosyal sistemlerin bir araya getirilme şeklinin, insanların davranışları, öğrendikleri ve öğrendiklerini nasıl öğrendikleri üzerinde bağımsı etkileri olduğunu ifade etmektedir. Eğitim paydaşlarının bir araya gelmeleri eğitim, eğitimciler, öğrenciler, öğretmenler ve yöneticiler üzerinde etkilidir. Bu sebeple milli eğitim müdürleri etkili yönetim sergilemek, hiyerarşiyi en aza indirmek, liderlik etmek, olumlu ilişki oluşturmak, açık, karşıllkll, çift yönlü ve yüz yüze iletişim modelinin okullarda kullanılmasını benimsemeyi tercih etmişlerdir (Kowalski vd., 2011, s. 4-10). Çünkü örgüt kültürü ve iletişim arasında pozitif ilişki vardır (Conrad, 1994, s. 27). Bu noktada iletişim, kültürel yatırım sağlar denilebilir.

Örgüt kültürü, yalnızca üst yönetimin bilinçli ikna edici stratejileri değil, tüm çalışanların iletişimsel eylemleri tarafindan ortaya çıkar ve sürdürülürler (Kowalski, 2000, s. 5-10). Birbirleriyle iletişim kuran insanlardan ayrı olarak mevcut değildirler. Diğer bir ifadeyle örgütsel iletişim örgütsel kültürün devamını sağlamaktadır (Kowalski, Petersen ve Fusarelli, 2007, s. 16). Çünkü iletişim kültüre yol açar, kültüre neden olur ve kültürün devamını sağlar (Axley, 1996, s. 153). Değişen kültürel yapı ile birlikte milli eğitim müdürlerinin yukardan aşağıya olan iletişim yapısı yeni iletişim türlerini de beraberinde getirmiştir (Heckman, 1993, s. 263-272). Milli eğitim müdürleri etkili iletişimci olmanın çok önemli olduğunu (Glass, Björk ve Brunner, 2000) ve iş performansını artırdığını bilerek, ona uygun çalışmalarını sürdürmelidirler (Kowalski vd., 2011, s. 4-10). Kısacası örgütte etkili çalışmalar yapmak için iletişimi etkin kullanmalarının önemli olduğu ifade edilebilir.

Takım lideri rolü (Team leader role): Takım çalışmaları örgüt içerisindeki kararsızlıkları, etkisiz işleyişi, tutarsızlıkları azaltabilir (Kıral, 2015). Etkili takımlar görevleri yerine getirmek için gerekli bilgi ve beceriye sahip, örgütsel ve mesleki bağllık ile aidiyete sahip, yetki ve sorumluluğun paylaşıldığı, özyönetime ve özdenetime sahip, şeffaf, hesap verebilir bir çalışma, birlikte ve ekip olarak iş yapabilme yetisine ve ortak hedeflere sahip; ödülleri, gücü ve başarıyı paylaşabilen, sinerji kurabilmiş kişilerden oluşmalıdır (Edmonson, 2012, s. 20-21). Çünkü örgütte yapılan takım çalş̧ması yöneticilerin işini kolaylaştırmakta, ortak paydada birleşen kişilerden oluştuğu için çatsşmaları ve çelişkileri ortadan kaldırmaya yardımcı olmaktadır (Lencioni, 2002). Takım üyeleri bilgi ve tecrübe paylaşımında bulunarak örgütü başarıya ulaştırabilirler (Wirt ve Kirst, 2001). Uzmanlardan oluşan takımlar işi iyi bir şekilde yapabilecekleri gibi, yöneticilerin zamandan tasarruf etmesini de sağlarlar (Owens ve Valesky, 2015). Takım çalısması sayesinde uzman kişilerden de istifade edilmekte, örgütlerde demokratik bir iklim hüküm sürmektedir (Sergiovanni, 2006). Takım çalışsmasının önemini bilen milli eğitim müdürleri de karar süreçlerini etkin yönetmek (Hirokawa, 1990, s. 190), işlerin uzmanlarınca hızlı bir şekilde en etkili şekilde yürütmesini sağlamak için takım çalışması yaparlar ve yapmalıdırlar (Wirt ve Kirst, 2001). Littlejohn (1992) toplumda meydana gelen sosyal, ekonomik, politik değişmeleri anlamak için milli eğitim müdürlerinin demokratik bir yaklaşım, tamamlayıcı iletişim ve liderlik ilkelerine uymalarını tavsiye etmektedir (Cappella, 1987; Ubben, Hughes ve Norris, 2004).

Örgüt içerisinde takımlar oluşturulabileceği gibi, aynı örgütün farklı kollarında da takımlar oluşturulmalıdır. Örneğin milli eğitim müdürünün kendi örgütü ile takım çalışması yapabileceği gibi, aynı şehirdeki farklı milli eğitim müdürlükleri ile de takım çalışmaları yapılabilir. Bunun için de milli eğitim 
müdürlerinin iyi takım liderleri olmaları, yetkilerini ve çift yönlü iletişimi aktif kullanmaları gerekmektedir (Cappella, 1987). Milli eğitim müdürleri ayrıca örgütsel fayda sağlamak amacıyla simetrik değiş-tokuş sürecini de kullanabilirler (Grunig, 1989; Grunig ve Huang, 2000). Güç paylaşımı, ikna edici tutum, güven, memnuniyet ve bağlllık ortamı oluşturmak, örgütsel sürdürülebilirliği ve dönüşümü en üst seviyeye çıkarabilir. Bu gibi sebeplerle milli eğitim müdürleri iyi birer takım lideri rolü üstlenmelidirler (Millar ve Rogers, 1976, s. 87). İyi takım liderleri olarak milli eğitim müdürleri, takım üyelerinin çıkarlarının sonuçları etkilemesine izin vermemelidirler. Bu da ancak takım üyelerini iyi tanımakla çözülebilir (Patton ve Downs, 2003). Başarılı takımların işlerliğini artırmak için, milli eğitim müdürlerinin birden fazla ve çeşitli kamu kurumları ve bunların iç gruplarıly simetrik ve sürekli bilgi alısverişinde bulunmaları (Reitz, 1987, s. 4961), dağıtımcı liderliği aktif kullanmaları, örgütsel ögrenmeye odaklanmaları ve bu konularda bilgi sahibi olmalar1 gerekir (Edmonson, 2012, s. 20; Katzenback ve Smith, 2004, s. 7-13). Milli eğitim müdürlerinin etkili takım liderleri olmaları işlerin kolayca çözülmesinde etkili olabilir.

Milli eğitim müdürleri ile ilgili yapılan araştırmalar (Arslan ve Atasayar, 2008; Björk, 2001; Björk, Kowalski ve Browne-Ferrigno, 2014; Çalışkan, 2017; Dak, 2019; Kowalski, 2001; Kowalski vd. 2011; Sümer, 2007; Yahşi, 2018 gibi) incelendiğinde "g̈grretmen adaylarmm milli eğitim müdürleri ile ilgili görüsslerinin alındı̆̆g” bir araştırmaya henüz rastlanılamamıştır. Bir yıl sonra öğretmen olarak göreve başlayacak olan öğretmen adaylarının görüşlerinin alınması ve bilgi düzeylerinin yoklanması, milli eğitim müdürleri hakkında bilgi düzeylerinin tespit edilmesi, özellikle Türk eğitim sistemi ve okul yönetimi gibi eğitim bilimleri derslerinde bu konuya eğilinmesi gereğini de ortaya koyabilecektir. Ayrıca bu araştırmadaki "milli eğitim müdürlerinin nasıl olması gerektiŭz’” ile ilgili kısmının milli eğitim müdürlerine de faydalı olacağ1 ve o yönde kendilerini geliştirmeye çalışabilecekleri ve böylece çalışmanın hem alan yazına hem de uygulamacılara faydalı olacağı söylenebilir. Bu önemden yola çıkarak yapılan araştırma öğretmen adaylarının milli eğitim müdürlerinin kim olduğunu, görev ve rollerinin neler olduğunu ve nasıl olmaları gerektiğini tespit etmek amacıyla yapılmıştır. Bu temel amaç doğrultusunda aşağıdaki alt problemlere yanıt aranmışır.

Öğretmen adaylarının;

1. Milli eğitim müdürlerinin kim olduğuna, görevlerine ve neye benzediğine ilişkin görüşleri nedir?

2. Milli eğitim müdürlerinin özelliklerine ilişkin görüşleri nelerdir?

3. Milli eğitim müdürlerinin olması gereken özelliklerine ilişkin görüşleri nelerdir?

4. Milli eğitim müdürlerinin rollerine ve rollerinin neye benzediğine ilişkin görüşleri nelerdir?

5. Gelecekte milli eğitim müdürü olmayı isteyip istemediklerine ilişkin görüşleri nelerdir?

\section{Yöntem}

Yapılan araştırma nitel araştırma olup; fenomenoloji deseninde yürütülmüştür (Creswell, 2016). Fenomenolojik araştırmalar bireylerin kendi bakış açısından, alg1 ve deneyimlerinin kullanıldığı bir araştırma desenidir. Fenomenolojik araştırmalarda olgu ya da deneyimin tanımlanması, bu tanımlamalardaki değişmeyen temaların ortaya konulması, bu temalara ilişkin kişisel görüşlerin belirlenmesi ve kişisel görüşler ile temaların birleştirilmesi esaslarını içermektedir (Ersoy, 2019). Bu çalışsmadaki fenomen “milli eğitim müdürï̀dür. Öğretmen adaylarının bu fenomenle ilgili görüşleri ortaya konulmaya çalışılmıştır.

\section{Katilımcilar}

Araştırma, 2019-2020 akademik yllı ikinci yarıylında bir devlet üniversitesinin eğitim fakültesinde öğrenim gören gönüllü 4. sınıf öğrencilerinin katıllımıla yürütülmüştür. Araştırmaya katılan öğrenciler amaçlı örnekleme yöntemlerinden ölçüt örneklem yöntemi kullanılarak seçilmişlerdir. Bu araştırmada kullanılan ölçütler öğrencilerin sayısal, sözel, eşit ağırlık ve yetenek alanlarından seçilmiş 4. sınıfta öğrenim gören öğretmen adayları olmalarıdır. Farklı branşların seçilme nedeni farklı bakış açlarını tespit etmektir. Ayrıca birkaç ay sonra öğretmen olarak mezun olacak öğrencilerin milli eğitim müdürleri ile ilgili bilgi düzeyini yoklamaktır. Araştırmaya başlamadan evvel ilgili üniversitenin eğitim fakültesinden "resmi yąıll iæ̧in ve etike kurul iæ̌ni” alınmıştır. Pandemi nedeniyle bazı öğrencilerle görüşmeler online ortamda, araştırmacının not tutması şeklinde olmuştur. Öğrenciler video kaydı tutulmasını istememişler, isim ve bölüm bilgilerinin gizli tutulmasını özellikle beyan etmişlerdir. Bazı öğrenciler ise araştırmacıya posta ve eposta ile görüşlerini iletmişler, bazı öğrenciler ise formu kendileri doldurup araştırmacıya sosyal mesafe kurallarına riayet ederek teslim etmişlerdir. Farklı şekillerde veri toplanmasının nedeni COVID-19 
pandemisi sebebiyle yüz yüze eğitim olmaması, online eğitim yapılmasından kaynaklanmaktadır. Ayrıca katılımcıların büyük çoğunluğunun da farklı şehirlerde ikamet etmesindendir. Öğrencilere ilişkin bilgiler Şekil 4'te verilmiştir.

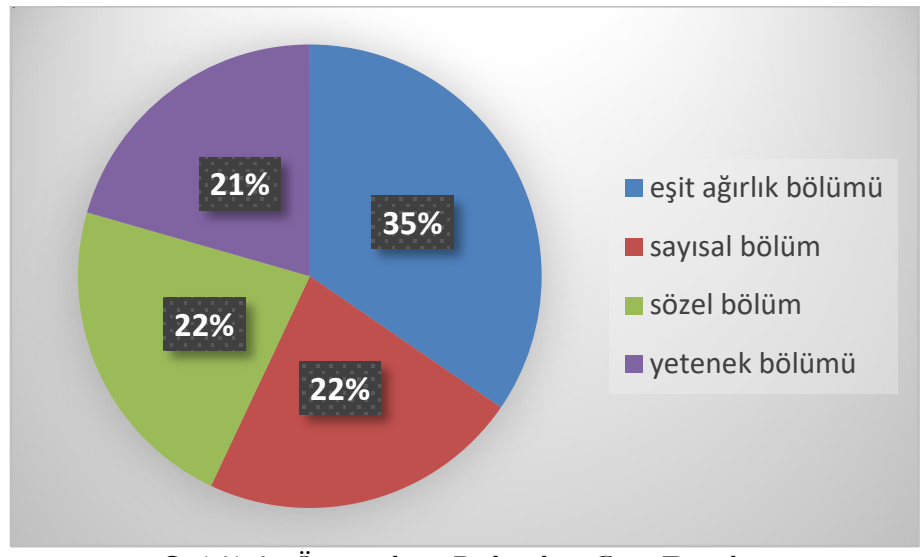

Şekil 4. Öğrencilerin Bölümlere Göre Dă̆gllımı

Şekil 4'te de görüldüğü gibi sözel bölümden 24, sayısal bölümden 24, eşit ağırlık bölümünden 37, yetenek bölümünden 22 son sınıf öğrencisi araştırmaya katılmıştır. Araştırmaya toplam 106 öğrenci katılmış olup; bunların 74’ü kız, 32'si erkek öğrencidir. Katılımcıların yaş aralığı 20 ile 25 arasında değişmektedir. Bölüm bilgisinin verilmesini bazı öğrenciler istemediği için araştırmada eşit ağırlık, sayısal, sözel ve yetenek bölümü olarak genel bir ifadelendirme kullanılmıştır.

\section{Verilerin Toplanması ve Analizi}

Araştırma için öncelikle alan yazın taraması yapılmış, gerekli okumalar yapılmış, alan yazındaki çalışmaların veri toplama araçlanı incelenmiştir. Ardından araştırmanın amacını gerçekleştirmek için alan yazından hareketle bir yarı yapılandırılmış veri toplama aracı oluşturulmuştur. Bu form hazırlanırken alanında uzman iki ögretim üyesinden uzman görüşü alınmış, formun yazım, noktalama kurallan ile ve anlatımı konusunda bir Türkçe öğretmeninden de ayrıca görüş alınmış, bunun neticesinde forma son şekli verilmiştir. Hazırlanan form öğrencilerin bazıları ile birebir görüşme yapmak suretiyle, bazılarına mail atarak, bazılarına elden vererek doldurtulmuştur. Öğrencilere milli eğitim müdürünün kim olduğu, rolleri, kafalarındaki milli eğitim müdürü imajı ile milli eğitim müdürünü neye benzettikleri vb. gibi soruları yazılı olarak cevaplamaları istenmiştir. Ardından toplanan verilerin analiz sürecine geçilmiştir. Araştırmada veriler içerik analizi ile çözümlenmiştir. Bunun için kategori ve alt kategoriler, kodlar araştırmacı tarafindan oluşturulmuştur. Verilerin kaçar kez tekrarlandığ1 araştırmacı tarafından sayılarak frekanslar verilmiştir. Araştırmaya katılan öğrencilerin sayısının fazla olmasından dolayı kod ad yerine numara verilerek çalışma içerisinde doğrudan alıntılara yer verilmiştir. Ayrıca çalışma içerisinde öğrencilerin bölümleri eşit ağırlık (EA), sayısal (SA), sözel (SÖ), yetenek (YE) ile; cinsiyetleri erkek (E) ve kadın (K) harfleri ile sembolize edilmiştir.

Araştırmada geçerlik için doğrudan alıntıların kullanılması ve yapılan analizin farklı bir araştırmacı tarafindan kodlattırılması yöntemleri kullanılmıştır. Güvenirlik içinse Miles ve Huberman (1994) formülünden yararlanılmış, uyum oranı tespit edilmiştir. Miles ve Huberman (1994) uyumun \%80 olmasının güvenirlik için yeterli olacağını ifade etmektedirler. Araştırmada tam uyum tespit edilmiştir. Buna göre araştırmanın güvenilir olduğunu söylemek mümkündür.

\section{Araştırmacının Rolü}

Araştırmacı araştırmada veri toplarken, verileri analiz ederken, yorumlarken ve yazıya geçirirken kendi şahsi görüş ve düşüncelerini araştırma dışında tutmuş, önyargilardan uzak bir şekilde objektif olarak çalısmayı yazıya geçirmiştir. Araştırma içerisinde etik unsurlara dikkat edilmiş, öğrencilerin bölüm bilgileri, isimleri gizli tutulmuş, kişisel bilgilerini içerecek ifadelerden kaçınılmışır. Araştırma için ilgili eğitim fakültesinden yazılı izin ve etik kurul izni alındıktan sonra, araştırmacı çalısmasına başlamışıtır. 


\section{Bulgular}

Araştırmanın alt problemine bağlı olarak sorulan sorulara verilen cevaplar doğrultusunda bu bölüm oluşturulmuştur.

\section{Milli Eğitim Müdürünün Kim Olduğu ve Görevleri}

Öğrencilere milli eğitim müdürünün kim olduğu ve görevlerinin neler olduğu sorusu yöneltilmiş bunun sonucunda aşağıda Şekil 5'deki kategoriler oluşturulmuştur.

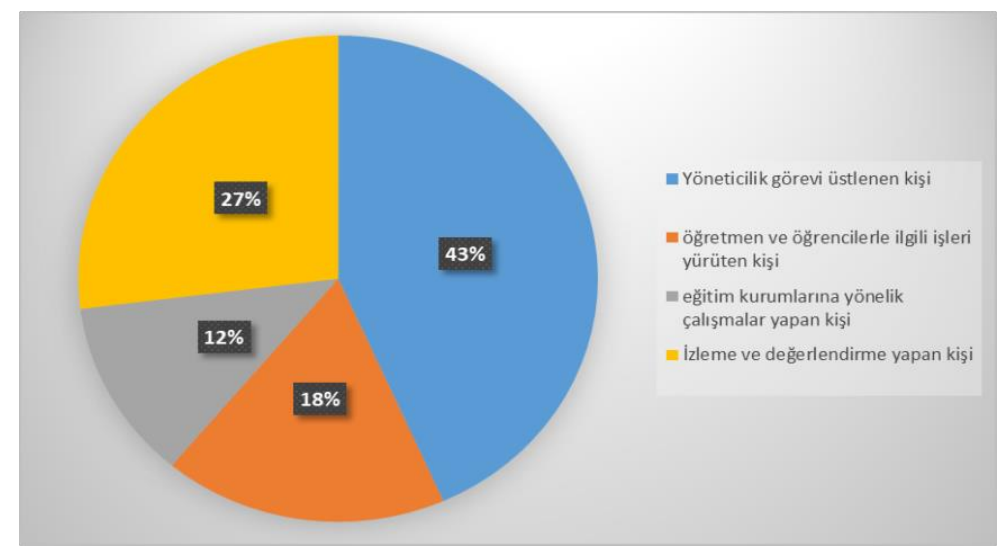

Şekil 5. Milli Eğitim Müdürünün Kim Olduğn ve Görevleri

Şekil 5’te görüldüğü gibi milli eğitim müdürlerinin kim olduğuna ilişkin bilgilerin kategorilere ayrılması sonucunda dört ana kategori oluşturulmuştur. Yöneticilik görevi üstlenen kişi; öğretmen ve öğrencilere yönelik çalışmalar yapan kişi; eğitim kurumlarına yönelik çalışmalar yapan kişi; izleme ve değerlendirmeye yönelik çalışmalar yapan kişidir. Yöneticilik görevi üstlenen kişi kategorisinde oluşturulan kodlar "eğitim faaliyetlerinin yürütülmesinden/yönetilmesinden sorumlu kişi (43), il/ilçede eğitimden sorumlu en üst yetkili (24), il/ilçelerde okullardan sorumlu kişi (17), il/ilçe eğitim yöneticisi (10), Bakanlığın verdiği görevleri yapan kişi (4)"; ögrretmen ve ögrrencilerle ilgili işleri yürüten kişi kategorisinde oluşturulan kodlar "tören, toplantı, proje, seminer vb. yapma (9), öğretmen açığını/ihtiyacını belirleme (7), bilgi verme(5), kadrolar (4), ücretli öğretmen ataması (3), sınav ve etkinlikler (3), yönlendirme (3), öğretmenlerle ilgili diğer işler (2), öğretmen disiplin işleri (1), öğrenciyi ödüllendirme (1), öğretmene görev verme(1), öğrenci ile ilgili diğer işler (1)"; eğitim kurumlarna yönelik, çalıs̆malar yapan kişsi kategorisinde olușturulan kodlar "okul ihtiyaçlan (10), eğitimle ilgili mali işler/bütçe (7), okullarla işbirliği (5), sorun çözme (5), okullara araç-gereç temini (4), okul sayısını belirleme (1)"; iそ̌leme ve değerlendirme yapan kişi kategorisinde olusturulan kodlar "plan ve program (27), denetleme (18), kontrol etme (4), değerlendirme (3), izleme (3), eğitimi geliştirmeye yönelik faaliyetler (3), okul ziyareti (1), okul yöneticileri ile iletişim(1), okul niteliğini/yeterliğini ölçme(1)" şeklindedir. Aşağıda katılımcıların görüşleri doğrudan alıntılarla verilmiştir.

Il ve ilgelerde bütün okullar bünyesinde toplayan, idari islerin, yönetmeliklerin, ortak karar ve düzenlemelerin ana koludur. Bulunduğu il ve ilcelerdeki okullarda bulunan ögretmen ibtiyaclarm, program eksikliklerini belirleyip gerekli üst kurumlara bildiren kişidir ( $\mathrm{E} A, K, 69)$.

Milli Eğitim Bakanlĭg tarafindan görevlendirilmis, il ve ilçelerdeki eğitim işleyişinden sorumlu kişi (YE, E, 96).

Eğitimle ilgili konular düzenler, uygulama olarak kararlar alir ve kararlar uygular. Örnek verecek olursak milli bayram kutlamalarmmn nasıl düzenleneceğini belirler. Milli eğitime bağg okullar denetler. Bir nevi eğ̈timde kontrol mekanizmasider (SÖ, E, 34).

İl veya ilse milli eğitim müdürleri ikisi de ayn işi yaparlar. Yani kendi alt bünyelerinde bulunan eğitim ile ilgili her türlü konuda organizasyon yapıp yönetirler. MEB'den gelen bilgileri ögretmenlere, okul müdïllerine aktarmmin sağlarlar. Kendi çevrelerinde eğitim ile ilgili sinavlarm hažrlanmasina veya sorun varsa bu sorunun kaynağznm belirlenmesi için toplantular düzenlerler $(S A, K, 9)$.

Araştırmada öğrencilere milli eğitim müdürünü görüp görmedikleri sorulmuş; verilen cevaplar neticesinde Şekil 6 oluşturulmuştur. 


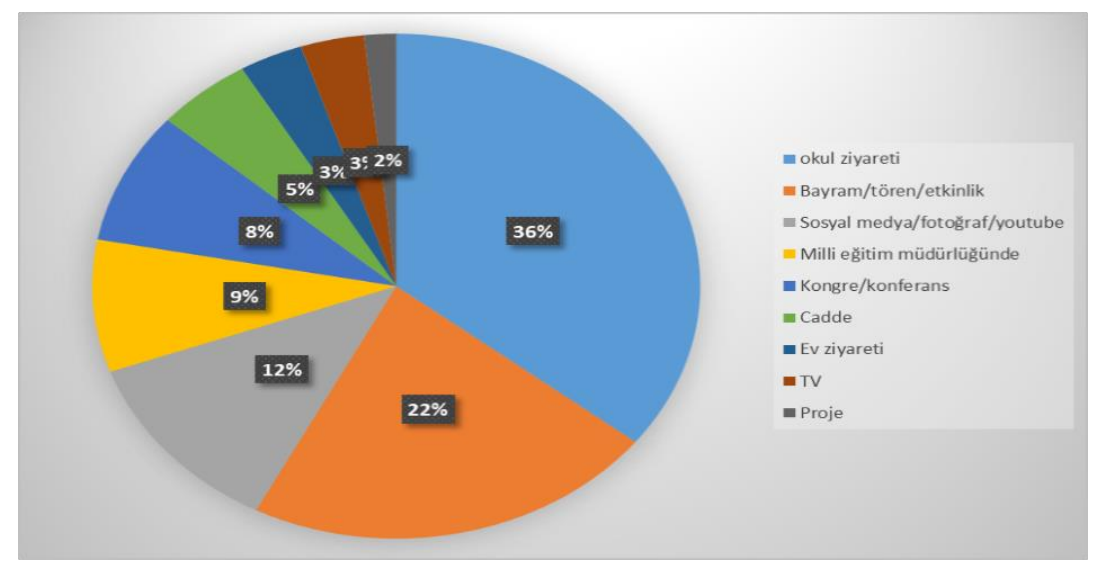

Şekil 6. Milli Ĕ̈gitim Müdürünün Görüldüğ̈̈ Yerler

Şekil 6 incelendiğinde öğrenciler milli eğitim müdürlerini en çok okul ziyaretleri esnasında ve bayram, tören, etkinliklerde gördüklerini ifade etmişlerdir. Bunları sosyal medya/fotoğraf/youtube/video, milli eğitim müdürlügünde, kongre/konferans, cadde, ev ziyareti, TV, projeler izlemiş ve bu başlıklarda kodlara ayrilmıştır. Aşağıda öğrenci görüşlerine yer verilmiştir.

23 Nisanda şïr yarş̧masinda 2. olduğunda ödülümü vermişsti ( $\mathrm{E} A, K, 70)$.

Köy okulu boyamaya gitmistitk. Orada bizi zijarete geldi. Teşekeür etti. Gelmesi mutlu etti (EA, E, 66).

Televisyonda gördï̈̆̈̈m bir milli eğitim müdürü vard. Bunun dişında baskea yerde görmedim. Herbangi bir şey dïssïnmemiștim o zaman ama șimdi eğitimle ilgili herhangi bir kisiyi gördügüumde algz olarak ona yöneliyorum (SÖ, $K, 48)$.

Özel günlerde görïyorduk. O da bazen. Bir de ilkokulda iken büyüle bir statta 10-15 okul toplanurd. Bizi selamlard biz de sağol derdik. Açıkşası çok resmi ortamlarda gördïk hep $(S A, K, 8)$.

Okula gelmişti. Okuldaki çalsşmalar, eksiklikleri, müdürü, okulu kısacası tüm çalışanlar kontrole geldig̈ini dïssïnmïstüm $(S A, K, 16)$.

Topluma bizmet uygulamalar dersi kapsaminda bir okulun bahse ve dis bakemyla ilgili görüsmeye gitmistik. Gittiğimizde neler yapabileceğimizi anlatt. Bize ekstra bilgiler verdi. Kendi fikirlerinden babsetti. Gördïgüumüzde bize karşı bir biyerarşik üstünlük fazla bissettirmedi $(\mathrm{E} A, K, 56)$.

Bir këy okulunu ziyaretinde görmïstüm. İlk bakessta yardma ibtiyacmuz olduğunda bunu yapabilecek biri olarak gördüm. Kadin olması sevindirdi ( $S A, K, 9)$.

Daha önce ilsce milli eğitim müdürü ile karşslasstum. Cinsiyeti kadindı. Giyimi, konuşmasi, durusu ile bende ayaklar yere sağlam basan, projelere önem veren, iletişimi iyi bir müdür iə̨lenimi boraktı $(S A, K, 4)$.

*Araştırma kapsamında sadece iki öğrenci kadın milli eğitim müdürü gördüğünü ve gurur duyduğunu ifade etmiştir.

\section{Milli Eğitim Müdürünün Özellikleri}

Milli eğitim müdürü gören öğrencilere milli eğitim müdürünün nasıl olduğu sorulmuş, verilen cevaplar neticesinde aşağıdaki Tablo 1 oluşturulmuştur. 
Tablo 1. Milli Eğitim Müdürlerinin Bedensel ve Giyim Özullikleri

\begin{tabular}{|c|c|c|c|c|c|}
\hline $\bar{O}$ zellik & Kodlar & $\bar{f}$ & $\ddot{O z z e l l i k}$ & Kodlar & $\bar{f}$ \\
\hline \multirow{15}{*}{$\begin{array}{l}\text { Bedensel } \\
\text { Özellikler }\end{array}$} & Konuşmas1/diksiyonu iyi & 17 & \multirow{15}{*}{$\begin{array}{l}\text { Giyim } \\
\text { tarzı }\end{array}$} & Takım elbiseli/resmi Giyim & 39 \\
\hline & Soğuk görünüşlü & 4 & & Şı/ /giyimi iyi & 16 \\
\hline & Diksiyonu kötü & 3 & & Temiz görünüşlü & 10 \\
\hline & Olgun & 3 & & Düzenli/bakımlı görünüş & 5 \\
\hline & Güleryüzlü & 3 & & Güneş gözlüklü & 2 \\
\hline & Orta yaşlı & 3 & & Kumaş pantolon & 1 \\
\hline & Biyıklı & 2 & & Gömlek & 1 \\
\hline & Sert bakışlı & 2 & & Kravat & 1 \\
\hline & Kel & 1 & & & \\
\hline & Şişman & 1 & & & \\
\hline & Beyaz şaçlı & 1 & & & \\
\hline & Uzun boylu & 1 & & & \\
\hline & Saçı başı düzgün & 1 & & & \\
\hline & Güler yüzlü & 1 & & & \\
\hline & Hizlı konuşma & 1 & & & \\
\hline
\end{tabular}

Tablo 1 incelendiğinde milli eğitim müdürlerinin özelliklerinin iki temel kategoriye ayrıldığ görülmektedir. Bunlar milli eğitim müdürünün bedensel özellikleri ve giyim tarzı kategorileridir. Aşağıda bu kategorilere ait katılımcıların görüşlerine örnekler verilmiştir.

Evet gördüm. Kaymakam ile yan yana oturuyordu. 29 Ekim törenlerinde sokakta yapilan yürüyüs ve kutlamalarda oturuyordu. Resmiydi. Takım elbiseliydi. Ciddi bir durusu vardı (SÖ, K, 32).

Gördüm sobbet ettim. Gayet özenli giyinen, durus ve diksiyonuna özen gösteren ve lider rolünü taşyan biriydi (EA, E, 73).

Evet. Bayramda törende konusma yapmuștı.....zorlanarak geldiği her halinden belliydi. Öğrencilerle temasa gecmedi bile. Fazla resmiydi. Sinirli konustu. Sanki biç sabr kalmamıs gibiydi (S A, K, 19).

Evet gördüm. Gayet resmi bir giyimi vardi. Cok otoriter gözüküyordu. Bakıslar net ve soğuktu. Diksiyon ve bitabetini yeterince başarıl bulmadım. Makam aracının olmasın da doğru bulmadım. Bana ögrencilerle mesafeli bir devlet adam izlenimi uyandirdı. (SÖ, E, 34).

Gördüm aile dostumuг, milli eğitim müdürüdür. Ö̊güveni yüksek, bilgi açısından donanmml, mesleki açdan yönlendirici ve yardimc olan bir beyefendidir. Dıs görünüsü mesleğine uygun, konusması ve davranıslar samimi, ancak mesafeyi iyi ayarlayabilen cinstendir. $(\mathrm{E} A, K, 60)$.

Daha önce sadece TV'de gördüm. Durusuyla bir konuda liderlik yapabilecek bilgi birikimine sahip olduğunu anlatıyordu. Konusması kendinden emindi. Giyim-kuşam ise yaptı̆̆ işe önem verdiğini gösteriyordu ( $\mathrm{E} A, K$, 58).

Geçen dönem katıldı̆̆ım bir programda ilçe milli eğitim müdürünü görmüstüm. Dıs görünüs, giyim-kusam olmasi gerektiği gibi resmiydi. Konuşma, durus, bakış yönünden pek tasvip etmediğim pasiflikte bir imaji vard. Konusmasm fazla etkileyici ve barekete geçirici bulmamıstım. Durusunda milli eğitim müdür ve yass bakermindan olgun olduğu için bir ağırlık vard, fakat özgüvenli bir tutumu yoktu. Ülkede çokça tipik meslektaşlar ile, siyasilerle benžer bir imaji vard. Ben bir özgünlük göremedim $(\mathrm{E} A, K, 51)$.

\section{Milli Eğitim Müdürünün Nasıl Olması Gerektiği}

Öğrencilere milli eğitim müdürünün nasıl olması gerektiği sorulmuş, bunun sonucunda dört temel kategori belirlenmiştir. Bunlar aşağıdaki Şekil 7’de verilmiştir. 


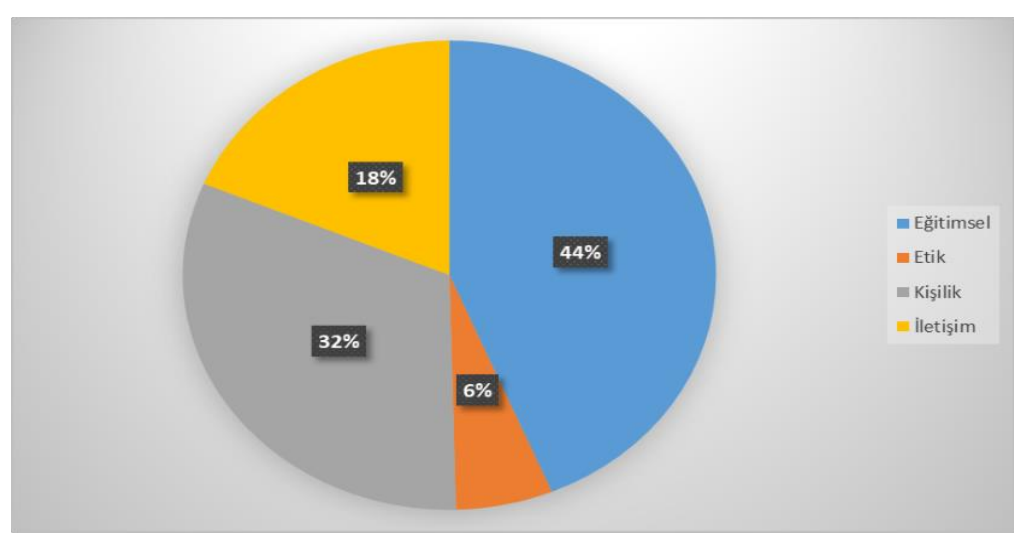

Şeki1 7. Milli Ë̆itim Müdürlerinin Olmasi İstenen Özellikleri

Şekil 7'de görüldüğü gibi öğrencilerin milli eğitim müdürlerinin olmasını istedikleri özellikleri eğitimsel açıdan, etik açıdan, kişilik ve iletişim özellikleri açısından kategorilere ayrılmıştır. Bu kategorilere göre öğrenciler en çok eğitimsel açıdan bir takım özellikler saymışlar, bunu kişilik, iletişim ve etik özellikler izlemiştir. Öğrencilerin verdikleri cevaplar neticesinde kategorilere ait kodlar ve frekans dağılımlarını içeren Tablo 2, 3, 4 ve 5 oluşturulmuştur.

Tablo 2. Milli Eğitim Müdürlerinin Olması Gereken Eğitimsel Özellikleri

\begin{tabular}{llrlr}
\hline Özellik & Kodlar & $\boldsymbol{f}$ & Kodlar & $\boldsymbol{f}$ \\
\hline & Eğitim düzeyi yüksek (yüksek lisans/doktora) & 58 & Bulunduğu yerin eğitimini geliştirmeye çalışmalı & 4 \\
& Tecrübeli (Öğretmen-yöneticilik yapmış) & 27 & Eğitim sorunlarıly ilgilenmeli & 4 \\
& Bilgili & 19 & Eğitimle ilgili bilimsel çalışmaları olmalı & 4 \\
& Örnek (eğitim açısından) & 18 & Eğitim sistemine hâkim olmalı & 3 \\
\multirow{2}{*}{ Eğitimsel } & En az üniversite mezunu olma & 16 & Erişimi kolay olmalı & 3 \\
açıdan & Okul ziyareti & 13 & Hedef koyabilmeli & 3 \\
& Eğitim fakültesi mezunu & 11 & Öğretmen-müdürlerle sık sık toplanmalı & 3 \\
& Kendini geliştirmeli & 11 & Profesör olmalı & 2 \\
& Sahada olmalı/odasında oturmamalı & 7 & Araştırmacı olmalı & 2 \\
& Başka ülkelerin eğitimi araştırmalı & 7 & Katılımcı yönetim benimsemeli & 2 \\
& Donanımlı & 6 & & \\
\hline
\end{tabular}

Tablo 2'de de görüldüğü gibi öğrenciler milli eğitim müdürlerinin yüksek lisans ve doktora derecesinde öğrenimli olması gerektiğini özellikle ifade etmişlerdir. Bunu öğretmenlik ve yöneticilik tecrübesinin olmas1, bilgili olması, örnek bir insan olması izlemektedir. Tablo 3'te ise katllimciların verdikleri cevaplar neticesinde milli eğitim müdürlerinde bulunması gereken etik özellikler tablolaştırılmıştır.

Tablo 3. Milli Eğitim Müdürlerinin Olması Gereken Etik Özellikleri

\begin{tabular}{llc}
\hline & Kodlar & $f$ \\
\cline { 2 - 3 } & Siyaset yapmamalı & 7 \\
& Alanında uzman & 5 \\
Adaletli & 4 \\
İnsancıl & 3 \\
Tarafsız & 2 \\
Etik açıdan & Haksılılı yapmamalı & 2 \\
& Yetkilerini doğru kullanmalı & 1 \\
& Torpil yapmamalı & 1 \\
& Adam kayırmamalı & 1 \\
& Yansı/objektif & 1 \\
& Doğru/dürüst & 1 \\
& Eşit & 1 \\
& Önyargilı olmamalı & 1 \\
\hline
\end{tabular}

Tablo 3’te de görüldüğü gibi öğrenciler en çok milli eğitim müdürünün siyaset yapmaması, alanında uzman olması, adaletli, insancıl ve tarafsız olması gerektiğini ifade etmişlerdir. Tablo 4'da ise öğrencilere göre milli eğitim müdürlerinde olması gereken kişilik özellikleri verilmiştir. 
Tablo 4. Milli Ë̆itim Müdürlerinin Olması Gereken Kişilik Öz̧ellikleri

\begin{tabular}{lllll}
\hline Özellik & Kodlar & $\boldsymbol{f}$ & Kodlar & $\boldsymbol{f}$ \\
\hline & Örnek kişilik & 18 & Yönlendirici & 3 \\
& Yeniliğe/değişime açık & 12 & Demokratik & 3 \\
& Özgüvenli & 12 & Durumun farkında olma & 3 \\
& Çözüm odaklı & 11 & Sevecen & 3 \\
& Kararlı & 8 & Gerçekçi & 2 \\
& Otoriter & 8 & Ilımlı & 2 \\
& Öğret./öğrenciye değer vermeli & 7 & Fedakâr & 2 \\
Kişilik & Ciddi & 7 & Duyarlı & 2 \\
özellikler & Yardımsever & 6 & Yapıcı & 2 \\
& Güler yüzlü & 5 & Sempatik & 2 \\
& Ileri görüş̧lü & 5 & Çağdaş/modern & 2 \\
& Atatürk inkılap ve ilkelerine bağlı & 5 & Pozitif & 2 \\
& Sicakkanlı & 5 & Çok konuşmama & 2 \\
& Anlayışlı & 5 & Sinirli olmama & 2 \\
& Lider & 4 & Katı olmama & 2 \\
& Güven verme & 4 & Teşvik edici & 2 \\
\hline
\end{tabular}

Tablo 4'da görüldüğü gibi öğrenciler milli eğitim müdürlerinde en çok örnek kişilik, yeniliğe/değişime açık olma, özgüvenli ve çözüm odaklı olmalarını istemektedirler. Öğrencilerin görüşleri doğrultusunda milli eğitim müdürlerinin iletişimsel özellikleri de araştırmacı tarafindan listelenmiştir. Milli eğitim müdürlerinin olması istenen iletişim özellikleri Tablo 5'de verilmiştir.

Tablo 5. Milli Eğitim Müdürlerinin Sahip Olması Gereken İletişim Öz̧ellikleri

\begin{tabular}{llc}
\hline & Kodlar & \multicolumn{1}{c}{} \\
\cline { 2 - 3 } & Düzgün diksiyon/Türkçeyi düzgün konuşma & 31 \\
& Etkili konuşma & 29 \\
İletişim & İyi iletişim & 11 \\
Özellikleri & Anlatım yeteneğinin yüksek olması & 8 \\
& Beden dilini kullanma & 8 \\
& İyi bir dinleyici & 6 \\
& Empati & 2 \\
\hline
\end{tabular}

Tablo 5'de görüldüğü gibi araştırmaya katılan öğrenciler milli eğitim müdürlerinin en çok diksiyonlarının düzgün olmasını/Türkçe'yi düzgün konuşmalarını istemektedirler. Bunu etkili konuşma ve iyi iletişim becerisi izlemektedir. Yukarıda oluşturulan Tablo 4, 5, 6 ve 7’ye ait katılımcı görüşleri aşağıda verilmiştir.

Eğitim fakültesinden mezun olmus, yükesek lisansin yöneticilik üzerine yapmış, insanlarla çok fąla iletişim balinde olduğu için iletisim becerisi yükesek, resmi dili çok iyi kullanmalı $(S A, K, 2)$.

Sadece şunu diyebilirim baksı̨llk yapmayan, siyasetten ayn gerçek bir eğitimci duruşu ile siyasi değil, eğitimi, okulu, ögrencileri temsil eden bir milli eğitim müdürü olmalıdır (YE, E, 103).

Bana göre öncelikle yurtdışın görmüs, yüksek lisansım, doktorasım yapmıs, dünya genelindeki eğitim kurumlarm araștırmış ya da bilgisi olan kültürlü ve kendini geliștirmis biri olmahdır. Diksiyonu doğru kullanan, kendini doğru ifade edebilen bir birey olmalidir (EA, K, 49).

Sadece makam koltuğunda oturmayan, çevresindeki okullarla, ögretmenlerle, yöneticilerle ve ögrencilerle iç içe olan, onlarn sorunlarna çözüm arayan ve eğitimle ilgili bir standart oluşturmay bedefleyen bir imaj hayal ediyorum. Eğitim düzeyi en az lisans düzeyi olmal ve eğitimin içinden gelen biri olmalı, konusması, duruşu, giyimi, diksiyonu düzgün olmalı (SÖ, $K, 40)$.

Milli eğitim müdürü eğitim camiasından olmal, ĕgitim ortamında iyice pişmiş, halden anlayan, ülkemin

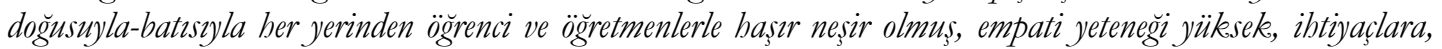
problemlere çözüm bulup, yeniliğe son derece açı biri olmalı $(S A, K, 13)$. 
KIRAL

Milli Ĕ̆gitim Bakanlığı Taşra Teşkilatı Yöneticileri: Milli Eğitim Müdürleri Üzerine Nitel Bir Çalışma

Son derece kibar ve açk fikirli, diksiyonu düzgün olmall. Mutlaka eğitimde yüksek yerlerde olmal, sadece lisans eğitimi ile sinurl kalmamalıdır. Atatürk'ün ilke ve inkılaplarm savunup, onlar uygulamalı ( $S A, K$, 18).

Ë̆itim düzeyi elbet ĕgitim dallarndan birinden olmah ve yükselebildiği yere kadar gelmis ve kendini gelistirmis olmali, konusması etkili ve harekete geçirebilen, ayn zamanda da umut aşılayan türden olmalı. Aym zamanda eylemleri kendi kararlarm uygulayabilecek, bir kesimin baskisi altında eğitime yön vermeyecek türden olmalıdır. Kararlarnm ve düsüncelerinin arkasinda sonuna kadar durabilen ve yenilikçi düsünceye sabip bireyler olmalıdırlar. Onlar için sadece resmi yaz̨l belgeler ve kararlar önemli olmamalıdır. Uyguladıklar yenilikęi projelerle adlar anulmalidir (E, $K, 51)$.

\section{Milli Eğitim Müdürlerinin Rolleri}

Öğrencilere milli eğitim müdürlerinin rolleri sorulmuş, buna göre aşağıdaki Tablo 6 oluşturulmuştur.

Tablo 6. Milli Eğitim Müdürünün Rolleri

\begin{tabular}{llc}
\hline & Roller & $\boldsymbol{f}$ \\
\cline { 2 - 3 } & Yönetici & 85 \\
& Öğretmen & 50 \\
& Eğitimci & 14 \\
& Denetleyici & 7 \\
& Öğrenci & 7 \\
& Veli & 3 \\
& Araştırmaci & 3 \\
Milli Eğitim Müdürünün & Anne-baba & 2 \\
Rolleri & Koordinatör/organizatör & 2 \\
& Lider & 2 \\
& Diktatör & 2 \\
& Bilgin & 1 \\
& Siyasetçi & 1 \\
& Kolluk kuvveti & 1 \\
& Baba & 1 \\
& Çözüm bulucu & 1 \\
& Aile & 1 \\
\hline
\end{tabular}

Tablo 6'de görüldüğü gibi öğrenciler milli eğitim müdürlerinin en fazla yönetici, öğretmen ve eğitimci rolleri olduğunu ifade etmişlerdir. Katılımcı görüşlerine örnekler aşağıda verilmiştir.

Pek çok rolü olabilir. En bașta yöneticilik ve liderlik pozisyonunun olması gerekir. Rasyonel kararlar almayn bilmeli, sorun tespitinde elestirilere açı olmal, ileri görüslü ve moderne dünyanın özelliklerine açı olmalı, en önemlisi ögretmenlik vasfina ve okul ortamına hâkim olmalıdır (YE, E, 20).

Ögrretmen ve yönetici rolünün ikisini de üstleniyor aslinda. Bilgi birikimi ve tecrübesiyle ögretmen, disiplinli ve dimdik ayakta duran tiplemeyle de yönetici rolünü üstleniyor. Cü̈kü milli eğitim müdürü hem ögrencilerin ve ibtiyaclarn ayn zamanda ĕgitim veren kurum ve ögretmenlere bilgi vererek ve disipliniyle de yöneticiliği elden birakmayan bir tavra büründüğ̈̈nden böyle düş̈nüyorum (SÖ, K, 28).

Milli eğitim müdürlerinin ögretmen rolü olmalıdır. Çünkü eğitim-ögretimle ilgili kararlar alırken ögretmen gözünden ögrencilerin ibtiyaçlarm anlayabilmeli ve aym zamanda ögretmenlerin ibtiyaçlarm da

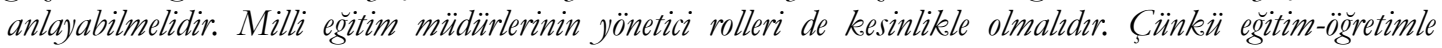
alakah onca kurum ve bu kurumlardaki insanlarn bir sekilde yönetilmesi gerekir. Yönetmeyi bilmezse ne kadar doğru kararlar alinirsa alınsın başarl olunamaz. (SA, K, 7).

Milli eğitim müdürlerinin rolleri deyince aklima ilk önce bir anne-baba rolü geliyor. Çünkü o da herşeyden önce bir ebeveyn ve bu görevindeki duyarliliğ başka cocuklara da göstermelidir. Bir anne şefkati ile çocuklara yaklasmali, bir baba gibi koruyn kollamalidir (SÖ, K, 36).

Bence ögretmenlerin, okul müdürlerinin, müdür yardımcalarmın hepsinin başında milli eğitim müdürü gelir. Bu kavramlar birbiriyle zincirlenmis gibidirler. Bu zincirin en başında milli eğitim müdürü geldiği için, eğitim ve ögretimle ilgili bütün düzenlemeleri, planlamalar, iyi bir şekilde yapmalıdır. Bundan sonraki çalısmalar okul müdürleri ve ögretmenler gerçekleştirir. Zincirin en başı sağlam ve dü̃günse, ortası ve sonunda kopukluklar olmaz: Bütün bunlardan dolayı milli eğitim müdürü bir yönetici rolündedir (SÖ, $K, 38$ ). 


\section{Milli Eğitim Müdürünün Neye Benzediği ve Sebepleri}

Öğrencilere milli eğitim müdürünü neye benzettikleri ve sebepleri sorulmuş, bunun neticesinde aşağıdaki Tablo 7 oluşturulmuştur.

Tablo 7. Milli Ë̆itim Müdürünün Neye Benzetildiği

\begin{tabular}{|c|c|c|}
\hline Kategori & Kod & $f$ \\
\hline Güç & $\begin{array}{l}\text { Aslan (2), Başkan (2), ailenin reisi, bilgili yönetici, bando yöneticisi, hakem, anne (5), padişah, kukla } \\
\text { oynatıcısı, antrenör (2), izci lideri, beyin (3), okul müdürü (4), baba, kaymakam/vali, hakim, meclis başkanı, } \\
\text { bakan, kraliçe arı (2), Sauron, anne-baba, rektör, AVM yöneticisi, trafik polisi, kalp, ağaç kökü (2), }\end{array}$ & 40 \\
\hline Fayda & $\begin{array}{l}\text { Su, kitap (2), bilgisayar (2), çatı, kürsü, kalem, tren, ağaç (3), ağaç gövdesi, ağaç kolu, güneş ışı̆̆ı, ana boru, } \\
\text { damar, güneş (3), saatin dişlisi, ormanc1, nar, satrançtaki vezir, } 360 \text { derece dönebilen kamera, sorgu odasının } \\
\text { arkasındaki kişiler, İsviçre saatinin çarkı, ahtapotun kolları, mum (3), cankurtaran, kartopu, baykuş, eşi } \\
\text { olmayan bir koca }\end{array}$ & 35 \\
\hline Olumsuz & $\begin{array}{l}\text { Domuz, patates, zürafa, sönmüş mum, karanlık, çarpışan arabalar, kukla, görünmez biri, gölge, piyano, } \\
\text { gurme }\end{array}$ & 14 \\
\hline \multirow[t]{2}{*}{ Üretim } & fabrika, arı (2), karınca (2), bahçıvan (2), toprak & 8 \\
\hline & Toplam & 97 \\
\hline
\end{tabular}

Tablo 7'da görüldüğü gibi milli eğitim müdürünün neye benzediği sorusu neticesinde güç, fayda, olumsuz, üretim olmak üzere dört kategori oluşturulmuştur. Aşağıda katılımcıların neye benzettikleri sebepleri ile birlikte verilmiştir.

Trene benzer çünkï bu tren ve arkasinda vagon sistemi varder. Bu biyerarşi ve sistem bir bütündür. Biri olmaz̧s diğerlerinin işleri aksar ve olumsuz sonuclar doğurur. Ayrlmaz bir bütündür (SÖ, E, 25).

Anne ve babaya benzer çünkü anne ve baba ailenin düreninden, sorunlarndan, iletişim ve ikliminden nasıl sorumluysa milli eğition müdürü de bunlardan sorumludur. Kendi alt bünyesinde büyü̈e bir alt aile olusturur $(S A, K, 9)$.

Trafik polisine benæer çünkü nasıl ki trafik, polisleri bir sürü yayalar, araçlar olması gereken şekilde yönetiyorsa milli eğitim müdürü de okullar, ögretmenleri, ögrencileri yönetir $(S A, K, 14)$.

Ağacn bir koluna benzer. Çünkü sistem ağacn kendisiyse ve ilçe/ il milli eğitim müdürleri ağacn her bir dah da milli eğitim müdürüne benzer ( $\mathrm{E} A, K, 78)$.

Kartopuna benzer çünkü eğer kartopu farkli kartoplar bir araya gelerek dev gibi bir kartopu elde edebilir. Müddür eğer kendi ile birlikte donanmm insanlarla el ele vererek, büyüyerek diğer insanlar da her alanda iyilestirir, geliștirir (EA, K, 55).

Güneşe benz̧er çünkü ögretmenler karbondioksit ve ögrenciler de ģigektir. Fotosentez için bu etmenler şarttur. Hayatın devam etmesi, geleceğimiz için çiçeklerin büyümesi ve üretmesi elz̧emdir (SÖ, E, 33).

Bir ar kolonisindeki kralice arya benzer. Çünkü milli eğitim müdürleri ve diğer yöneticiler her zaman kendi altlarnda bulunan insanları yöneterek halkemm ibtiyaçlarmı karşzlamaya çalısır (EA, E, 50).

\section{Milli Eğitim Müdürünün Rollerinin Neye Benzediği ve Sebepleri}

Milli eğitim müdürünün rollerinin neye benzediği ve sebepleri öğrencilere yöneltilmiş, bunun neticesinde Tablo 8 oluşturulmuştur.

Tablo 8. Milli Eğitim Müdürünün Rollerinin Neye Benzetildiüi

\begin{tabular}{|c|c|c|}
\hline Kategori & Kodlat & $f$ \\
\hline $\begin{array}{l}\text { Gereklilik olarak } \\
\text { roller }\end{array}$ & $\begin{array}{l}\text { Sistem, çark, zincirin halkaları, yönetici (3), liderlik (3), bisiklet pedalını çevirme, manto, köprü, } \\
\text { antivirüs programı, saatin küçük bir dişlisi, düzenleyici, tek yüzük, İsviçre saatinin çarkları, } \\
\text { bahçvanın malzemeleri, damar, bahçıvan, memur, kukla ipleri, Makinenin başlatma tuşu, aslan, } \\
\text { kraliçe arı (2), antrenör, hakim, okul yöneticisi (6) }\end{array}$ & 34 \\
\hline $\begin{array}{l}\text { Fayda sağlayıcı } \\
\text { olarak roller }\end{array}$ & $\begin{array}{l}\text { Apartman yöneticisi, çok amaçlı bez, tohum, ağacın dalları (2), bilgisayar, bukalemun, ağaç, tarla, } \\
\text { robot, piyano, masa, şef (2), üç ayaklı bir kazan, adab-1 muaşeret kuralları, çınar ağacı, ahtapot, nar, } \\
\text { Orhun kitabeleri, kelebek etkisi, ilaç, rektör, orman, kalem, Peygamber }\end{array}$ & 27 \\
\hline Zorunlu roller & $\begin{array}{l}\text { Anne (5), baba (4), güneş ışınları, gelişim evreleri (çocuk, yetişkin, dede), ebeveyn (3), aile içindeki } \\
\text { sorumluluklar }\end{array}$ & 15 \\
\hline $\begin{array}{l}\text { Gerektiğinde } \\
\text { ortaya çıkan roller }\end{array}$ & $\begin{array}{l}\text { Cumhurbaşkanı sözcüsü, koltuk sevdalıları, dizi oyuncusu, tiyatro oyuncusu, lider (2), eğitmen, film } \\
\text { yönetmeni, bebek bakıcısı }\end{array}$ & 9 \\
\hline Toplam & & 85 \\
\hline
\end{tabular}


KIRAL

Milli Ĕ̆gitim Bakanlığı Taşra Teşkilatı Yöneticileri: Milli Eğitim Müdürleri Üzerine Nitel Bir Çalışma

Tablo 8'de de görüldügü gibi milli eğitim müdürünün rolleri gereklilik, fayda, zorunlu, gerektiğinde ortaya çıkan roller olarak kategorilere ayrılmıştır. Aşağıda bu rollerin neye benzediği ve sebeplerine ilişkin katılımc1 görüşleri verilmiştir.

Aslana benそetiyorum çünkü bir aslann ormandaki diğer hayvanlar yönlendirmesi gibi onlarn da ögrretmenleri yönlendirdiğini dïsïnüyorum. ( $\mathrm{E} A, K, 62)$.

Antrenöre benæ̧etiyorum. Çünkü bütün ildeki okullarn kurallarm, eğitim-öğretimin planlanmasm, herșeyi sistematik bir şekilde dürenlediği için (YE, E, 98).

Mantoya benæetizorum çünkü eğer bu rollere sikeca sarlirlarsa rollerle birlikte eğitimi de ssitabilirler ancak bu rolleri üstlerine geçirmezlerse biçbir işe yaramaz $(\mathrm{E} A, \mathrm{E}, 81)$.

Peygamberin rollerine benzetiyorum çünkü peygamber dini yaymaya çalssyor buna ortam bažrllyor. Milli eğitim müdürleri de ilim yaymaya ve buna ortam ba:srllyor (EA, E, 83).

Annenin rollerine ben₹etiyorum çünkü anne evde çocuklarmmn eksiğ kalmasin, tam olsun isteyen, Çocuğunun başarli olmast için çabalayan kişiyse milli eğitim müdürü de bir yerde anne rolïndedir ( $\mathrm{E} A, K, 85)$.

Köprï̈e benzetiyorum çünkü iki taraf arasinda iliski kurar. Kendi alt kurumlarn ile üst kurum bakanllk arasinda bağ kurar (EA, $K, 56)$.

\section{Gelecekte Milli Eğitim Müdürü Olmayı İsteme Durumu}

Gelecekte milli eğitim müdürü olmak ister misiniz şeklinde bir soru sorulmuş, bunun neticesinde evet ve hayır kategorileri oluşturulmuştur. Aşağıda öğrencilerin cevapları neticesindeki kodlardan Şekil 8 oluşturulmuştur.

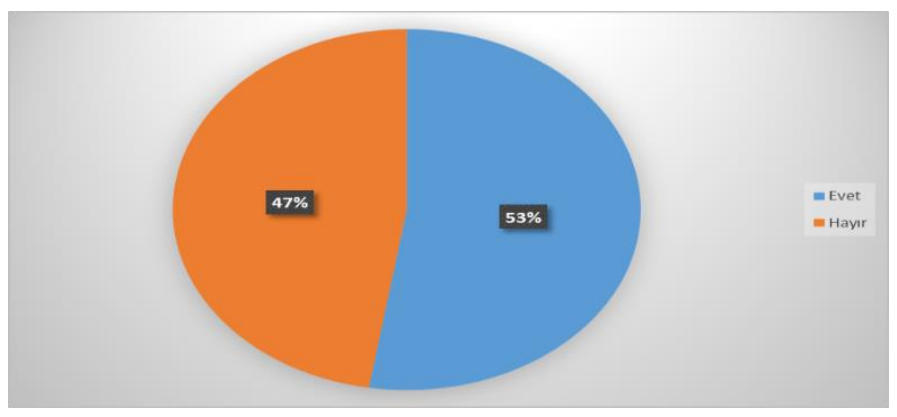

Şekil 8. Milli Eğitim Müdürü Olmayı İsteme ve İstememe Durumu

Şekil 8'e göre evet cevabının daha fazla olduğu görülmektedir. Milli eğitim müdürü olmak istemeyen hayır cevab1 veren öğrencilere neden istemedikleri, evet cevab1 veren İsteyen ögrencilere ise hangi çalışmaları yapmak istedikleri sorulmuş; bunun sonucunda aşağıdaki Tablo 9 ve 10 oluşturulmuştur. Öncelikle hayır cevabı öğrencilerin cevaplarını içeren Tablo 9 verilmiştir.

Tablo 9. Gelecekte Milli Ë̈itim Müdürü Olmayn İstememe Nedenleri

\begin{tabular}{|c|c|c|c|}
\hline \multirow{18}{*}{$\begin{array}{l}\text { Hayır } \\
\text { cevab1 } \\
\text { verenlerin } \\
\text { nedenleri }\end{array}$} & Kategori & Kod & $\bar{f}$ \\
\hline & \multirow{11}{*}{ Kişisel nedenler } & İyi bir öğretmen olmak/ Mesleğinden ayrılmak istememe & 17 \\
\hline & & Kendisini yeterli hissetmeme & 7 \\
\hline & & Hedef/idealin bu olmaması & 3 \\
\hline & & Yönetici vasfının olmadığı düșüncesi & 3 \\
\hline & & Okulların sorunları ile uğraşmanın onu mutlu etmeyeceği düşüncesi & 3 \\
\hline & & Milli eğitim müdürünün görevlerinin tam olarak bilinmemesi & 3 \\
\hline & & Kimsenin adamı olmak istememe & 2 \\
\hline & & İyi bir eğitim sisteminde yetişmediği düşüncesi & 1 \\
\hline & & Yazı işlerinin sevilmemesi & 1 \\
\hline & & Çevresindekilerin sözünü dinlemek zorunda olması & 1 \\
\hline & & Resmi ortamda olmak istememe & 1 \\
\hline & \multirow{6}{*}{$\begin{array}{l}\text { İşten kaynaklanan } \\
\text { nedenler }\end{array}$} & Sorumluluk gerektirmesi & 19 \\
\hline & & Bağımsız/istediği gibi karar aldırmazlar düșüncesi & 3 \\
\hline & & Zor bir görev olduğu düșüncesi & 3 \\
\hline & & Düzen kurmak, otorite kurmanın zor olduğu düșüncesi & 3 \\
\hline & & İdari işlerin sıkıcı olması & 1 \\
\hline & & Sistemin düzelmeyeceği, boşa uğrașmak istememe düșüncesi & 1 \\
\hline
\end{tabular}


Tablo 9'de görüldüğü gibi öğrencilerin neden milli eğitim müdürü olmak istemediklerine ilişkin görüşleri kişisel nedenler ve işten kaynaklanan nedenler olmak üzere iki temel kategoriye ayrilmıştır. Burada dikkati çeken en önemli iki husustan birincisi öğrencilerin iyi öğretmen olmak istemesi ve mesleklerinden ayrılmak istememeleri ile sorumluluk gerektiren işleri istememeleridir. Aşağıda katılımcıların verdiği cevaplar doğrudan alıntılarla verilmiştir.

Bu ve benzeri mevkilere fursat bulunca bemen saldran koltuk sevdallarn yerine bu işi hakkecyla yapabilecek insanlar getirilmelidir. Bu sebeple kendi yetenek ve becerilerim arasinda bulunmadiğn düssündï̈ğ̈̈m liderlik, krizyönetimi vs. gibi özelliklerden dolayı böyle bir mevkiye gelmek istemezdim (E A, E, 50).

Hayır, milli eğitim müdürü olmak istemem. Yönetici, idareci vasfim olduğgnu sanmıyorum (EA, $K, 71)$.

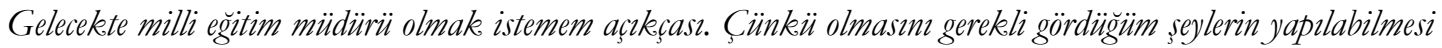
için en önemli şey olan iletişim gücünün benim kuvvetli yönüm olduğunu düş̈̈nmüyorum $(S A, K, 5)$.

Milli eğitim müdürü olmak istemezdim. Bu görevi yapmak meşakkatli bir görev. Tüm okullarn işleyişini düzenlemek, otoriter olmak zor bir görev (SÖ, K, 36)

Hayır, olmak istemem şünkü okulda ögrencilerle vakit geçirmek daha güzel (SÖ, K, 29).

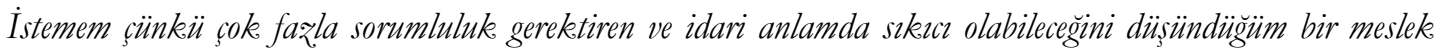
(EA, K, 69).

Hayur, istemem sadece ögretmenligimin iyi ve saygin olmasm isterim ( $S A, K, 18)$.

Olmak istemem çünkü şimdilerde hep birileri birilerinin adamı. O yüzden öyle mertebeli yerlerden uzak durmak en iyisi (EA, E, 67).

Olmak istemem. Ögrretmen olarak. kü̧⿻ük kalplere dokunmak, bana büyük mutluluk katar (SÖ, K, 48).

Hayır, çünkü istediklerimi yapmama iz̧in vermęler (EA, E, 66).

İstemem iyi bir ögrretmen olayım yeter $(\mathrm{E} A, K, 72)$.

İstemem çünkü ögretmenlike daha çok hayalini kurduğum ve kendime yakusstrdrăgrm bir meslek. Milli eğitim müdürü olmak daha çok resmi işlerle ilgilenmek demek. Resmiyetin içinde olmak istemem $(\mathrm{E} A, K, 56)$.

Gelecekte milli eğitim müdürü olmak isteyen öğrencilere ise milli eğitim müdürü olduklarında neler yapacakları sorulmuş, verdikleri cevaplar neticesinde aşağıdaki Tablo 10 oluşturulmuştur.

Tablo 10. Gelecekte Milli Eg̈̈tim Müdürü Olmayı İsteme Nedenleri

\begin{tabular}{|c|c|c|c|}
\hline \multirow{26}{*}{$\begin{array}{l}\text { Evet' } \\
\text { se } \\
\text { yapila } \\
\text { caklar }\end{array}$} & Kategori & Kod & $\bar{f}$ \\
\hline & \multirow{16}{*}{$\begin{array}{l}\text { Ĕgitimsel- } \\
\text { Öğretimsel } \\
\text { faaliyetler }\end{array}$} & Eğitimsel projeler, çalıșmalar & 8 \\
\hline & & Firsat-imkân esitliği sağlamak & 7 \\
\hline & & Eğitim sistemini değistirmek & 3 \\
\hline & & Aile eŏitimleri & 2 \\
\hline & & Özel eğitim gereksinimi olan öğrencileri topluma kazandırma & 1 \\
\hline & & Șehit öğretmenlerin unutulmaması için faaliyetler & 1 \\
\hline & & Yeniliklere acık olmak & 1 \\
\hline & & Dünvadaki eğitim faalivetlerini takip etme & 1 \\
\hline & & Öğretmen seçiminin incelikle yapılması & 1 \\
\hline & & Hayat boyu eğitim faaliyetlerini artırma & 1 \\
\hline & & Öğretmen eğitimleri & 1 \\
\hline & & Sorunları çözme & 1 \\
\hline & & Öğrencilerin ilgilerine göre yönlendirilmesi & 1 \\
\hline & & Çă̆daş eğitimin benimsenmesi & 1 \\
\hline & & Eğitim seviyesini iyileştirme & 1 \\
\hline & & Sınava yönelik eğitimi engellemeye çalışma & 1 \\
\hline & \multirow{9}{*}{$\begin{array}{l}\text { Kissisel } \\
\text { faaliyetler }\end{array}$} & Etik faaliyetler (adalet, eşitlik, liyakat, ayrımcllık yapmama gibi) & 5 \\
\hline & & Okulları araştırma, kontrol, denetleme & 5 \\
\hline & & Siyasetten uzak durmak/siyaset yapmamak & 3 \\
\hline & & Ĕgitimde kardeşlik anlayışı oluşturmak & 2 \\
\hline & & Daha iyi, yararlı olmak için çalıșma & 2 \\
\hline & & Daha aktif olup, hizmetlerin okullara hızlı gitmesini sağlama & 2 \\
\hline & & Ulașilabilir bir makam olma & 1 \\
\hline & & Bölgevi tanımak & 1 \\
\hline & & Okullarda vicdan anlavıșı gelistirmek & 1 \\
\hline
\end{tabular}


KIRAL

\begin{tabular}{|c|c|c|c|}
\hline & & $\begin{array}{l}\text { Vatandaşlık bilinci oluşturmak, iyi insan yetiştirmek } \\
\text { Daha çok çalışıp, kendini geliştirmek } \\
\text { Örnek bir yönetici olmak } \\
\text { İşi zorunlu değil, severek yapmak }\end{array}$ & $\begin{array}{l}1 \\
1 \\
1 \\
1\end{array}$ \\
\hline \multirow{3}{*}{$\begin{array}{l}\text { Evet' } \\
\text { se } \\
\text { yapila } \\
\text { caklar }\end{array}$} & $\begin{array}{l}\text { Ë̆itim } \\
\text { ortamlarına ve } \\
\text { materyallerine } \\
\text { yönelik } \\
\text { faaliyetler }\end{array}$ & $\begin{array}{l}\text { Eğitim ortamlarını daha iyi yapmak } \\
\text { Öğretmenlerin/okulların fiziki eksikliklerini karşılamak } \\
\text { İmkânları artırma } \\
\text { Sınıf mevcutlarını minimumda tutma } \\
\text { Eğitime rahat erişim sağlama } \\
\text { Güvenli ortam oluşturma } \\
\text { Sosyal etkinlik alanları düzenleme } \\
\end{array}$ & $\begin{array}{l}6 \\
2 \\
1 \\
1 \\
1 \\
1 \\
1\end{array}$ \\
\hline & $\begin{array}{l}\text { Sosyal-kültürel } \\
\text { faaliyetler }\end{array}$ & $\begin{array}{l}\text { Sosyal etkinlikler (sanatsal, sportif vb.) } \\
\text { Çocukların hayal güçlerini geliştirmeye yönelik çalışmalar }\end{array}$ & $\begin{array}{l}7 \\
1\end{array}$ \\
\hline & $\begin{array}{l}\text { Yardım } \\
\text { faaliyetleri }\end{array}$ & $\begin{array}{l}\text { Öğrencilerin maddi ve manevi ihtiyaçlarının karşılanması/en aza indirilmesi } \\
\text { Eğitim-öğretim, okulların ihtiyaçlarını karşılamak }\end{array}$ & $\begin{array}{l}4 \\
2\end{array}$ \\
\hline
\end{tabular}

Tablo 10 incelendiğinde milli eğitim müdürü olmak isteyen öğrencilerin görüşlerine göre eğitimöğretimsel faaliyetler, kişisel faaliyetler, eğitim ortamlanına ve materyallerine yönelik faaliyetler, sosyalkültürel faaliyetler ve yardım faaliyetleri olarak kategorilere ayrilmışır. Bunlardan en çok eğitimsel projeler yapmak, firsat ve imkân eşitliği yaratmak, eğitim ortamlarını daha iyi yapmak, sosyal etkinlikler yapmak amacıyla milli eğitim müdürü olunmak istenmektedir. Aşağıda katıllımcıların görüşleri doğrudan alıntılarla verilmiştir.

Olmak isterim olursam eğer sanata, güzel sanatlara ve yetenekli ögrencilere daha çok önem veririm (YE, E, 102).

Isterdim önceliğim aile eğitimi olurdu. Okullarda aile eğitimi ile ilgili çalsmalar yapardm $(\mathrm{E} A, \mathrm{~K}, 65)$.

Isterim mevki olarak yükselip ayn zamanda eğitim hayatınn içinde olabilirim. Önceliklerim okullarn ibtiyaçlar, kütüphaneleri ve sosyal etkinlik alanlar olur (E $A, K, 76)$.

Evet, isterim okullar arasttrrrm. Ë̆itimi nasıl daha iyi ilerletip ögrencilere nasıl daha yararl olabilirim sürekli bunun üzerinde düş̈̈n̈̈rüm. Bu yönde çalsşmalar yaparm $(S A, K, 3)$.

İsterdim. Önceliklerim ögrenci ve ögretmen ibtiyaçlarna yeterli özeni göstermeye gayret etmek olur. Cünkü eğitim için gerekli en önemli iki unsurun eğitimin tüm yetkililerini ilgilendiren bir meseledir (SÖ, K, 42).

Isterim tabi, siyasetten uzak olmaya çallşırdm. Siyasetle eğitimi karrştrmazdim (YE, E, 103).

Bir gün milli eğitim müdürü olursam ilkokulda yasad̆ğm tüm zorluklar göz önünde bulundurarak, ögrencilerin eğitim ortamma rahat ulașabilmesini, kendini ifade edebileceği bir ortamm hątrlanmasın ve ögrenci ibtiyaçlarmm karşılanmasin sağlardim (SÖ, E, 37).

Olmak isterim. Öncelikle yapacağrm ilk is bölgemi tanmak olur. Daba sonra bulunduğum bölgedeki insanlar için eğitim açısindan firsat eşitliği sağlamak için elimden geleni yaparm. Okullarla sürekli etkinlikler düzenler socuklar için daha iyi ortamlar olustururum (E $A, K, 55)$.

Evet isterim. Okullarda daba çok vakit geçirmeye çalş̧ım. Durumu olmayan ögrencilere direkt ulaşırm. Her çocuğun eğitim alma bakker vardr. Maddi ve manevi sikentılar en aza indirmeye çalsşrm (SÖ, E, 33).

Gelecekte olmak istiyorum ama tam olarak kendimi o makama ve sorumluluğa hazır hissetmiyorum. Daba çok

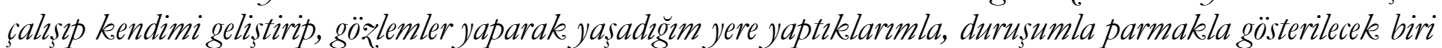
olmak isterim. Önceligüim öğrenciler olacağg için, ögrencilerin gelismesi için, her türlü faaliyeti makamon el verdiğince yapmak isterim. Bunu üst makamlarla konusup yine de halletmeye çalsşrmm. Öğrencileri sanat, tiyatro, sinema alanlarnda gelismeleri için sosyal etkinliklere tessvik ederim (SÖ, $K, 41$ ).

Okullarda kurallara uyulup uyulmadiğzn kontrol ederim. Haksızllk. yapılhp yapılmadĭgm denetlerim. Güvenli ortam olusturulması için desteklerim ( $S A, K, 24)$.

Isterim. Ë̈̆timde firsat eşitliği ve kökten yeni bir eğitim sistemini bu işin užmanlaryla tasarlamak isterim (EA, $K, 57)$.

Hep yeniliklere açık olup, düny a genelini takip ederdim. Cağga uygun eğitim șartlar sağlamaya çalısırdım. Simf mevcut sayısm minimum tutardm. Okul bahçelerini, sinflar çocuklarm sevebileceğg sekilde tasarlardim. (EA, K, 49). 


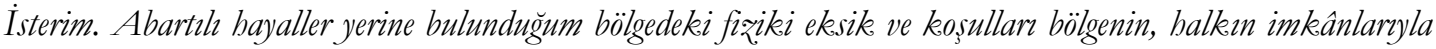 çö̌meye çalssmak isterdim (E A, E, 73).}

\section{Sonuç, Tartışma ve Öneriler}

Araştırma milli eğitim müdürlerinin kim olduğunu, görevlerini ve rollerini, nasıl olmaları gerektiğini eğitim fakültesi son sınıf ögrencilerinin gözünden ortaya koymak amacıyla yapılmıştır. Araş̧ırmada son sınıf öğrencilerinin seçilme nedeni dört yıl boyunca öğretmen olmak için yetiştirilmiş, eğitim sistemi hakkında genel bilgiye sahip olan, okullara staja giderek sistemi görme şansı elde eden ve kısa bir süre sonra öğretmen olarak eğitim sistemine girecek olmalarındandır. Araştırma kapsamında milli müdürleri yöneticilik görevi üstlenen, öğretmen ve öğrencilerle ilgili işleri yürüten, eğitim kurumlarına yönelik çalısmalar yapan, izleme ve değerlendirme yapan kişi kategorilerinde değerlendirilmiştir. Öğrencilerin büyük çoğunluğu milli eğitim müdürünü görmüş olduğunu ifade etmiştir. Milli eğitim müdürünün en çok görüldüğ̈̈ yerler müdürlerin okul ziyaretleri, bayram, tören, kutlama gibi etkinliklerde, sosyal medya, video gibi sosyal içerikli platformlardadır. Gördükleri milli eğitim müdürünün nasıl olduğu sorulduğunda diksiyonu iyi, takım elbiseli, resmi, soğuk görünüşlü olduğuna ilişkin cevaplar verilmiştir.

Öğrencilere milli eğitim müdürlerinin hangi özelliklere sahip olması gerektiği sorulduğunda ise öğrencilerin verdikleri cevaplar doğrultusunda dört temel kategori oluşturulmuştur. Eğitimsel, kişilik, iletişimsel ve etik özellikleridir. Bu kategorilerden en fazla olması istenen milli eğitim müdürlerinin lisansüstü düzeyde eğitimli olması gerektiğidir. Kişilik bakımından örnek olmaları gerektiği, yeniliğe, değişime açık olmaları gerektiği de ayrıca vurgulanmıştır. Bunların dışında milli eğitim müdürlerinin siyasetten uzak durmaları, siyaset yapmamaları, adaletli olmaları da ifade edilmiştir. İletişime ilişkin becerileri ise düzgün diksiyon, etkili konuşma, Türkçe'yi güzel konuşma en çok tekrarlanan ifadelerdendir. Öğrencilerin yarıdan fazlası milli eğitim müdürü olmak istemekte, diğer kısım ise öğretmenlik mesleğini sevmelerinden, iş yükünün fazla olmasından, işin fazla sorumluluk içermesinden, kendilerinde yöneticilik vb. gibi vasıflar olmamasından dolayı milli eğitim müdürü olmak istememektedirler. Milli eğitim müdürlerinin hangi rollerinin olduğu sorulduğunda ise yönetici, anne-baba, öğretmen, denetleyici gibi rolleri olduğu ifade edilmiştir. Milli eğitim müdürlerinin neye benzediği sorulduğunda ise güç, fayda, olumsuzluk, üretim kategorilerinde görüşler bildirilmiştir. Bunlardan ise en çok güç kategorisindeki kodların yoğun olarak ifade edildiği görülmektedir. Rollerinin neye benzediği sorulduğunda ise gereklilik, fayda, zorunluluk, gerektiğinde ortaya çıkan roller olarak kategorilendirilmiştir. Bunlardan ise en çok tekrar edilen gereklilik olduğudur.

Milli eğitim müdürlerinin rolleri, görevleri vb. ile ilgili yurt dışında yapılan araştırmalar (Björk, 2001; Björk, Kowalski ve Browne-Ferrigno, 2014; Kowalski, 2001; Kowalski vd. 2011 vb. gibi) incelendiğinde özellikle Amerika'da yoğun bir şekilde çalışmalar yapıldığı görülmektedir. Bunun sebebi Amerika'da az okullu küçük eğitim bölgeleri olması, milli eğitim müdürlüklerinin sayısının fazla olması, sayıca daha fazla milli eğitim müdürü olması, milli eğitim müdürlerinin dil, din, cinsiyet, etnik köken, ırk gibi farklı özelliklerden oluşmasından dolayı daha derin ve kapsamlı araştırmalara yol açmış olduğu söylenebilir. Amerika'da milli eğitim müdürlüklerinin bölgesel olarak ayrılarak görevlerini yerine getirdikleri, küçük eğitim bölgelerinde görev yaptıkları, bu sebeple de sorumluluk alanlarının daha az olduğu, sürekli iyileşmeye odaklandıkları görülmektedir. Türkiye'de ise milli eğitim müdürlükleri bölgesel olmayıp il ve ilçe düzeyinde görev yapmaktadır. Sorumlu oldukları alanın daha geniş olması sebebiyle daha fazla iş yükü ile karşılaştıkları, sorunlara daha geç müdahale edildiği, okullara yeterince gidemedikleri için personeli ve öğrencileri yeterince tanıyamadıkları söylenebilir. Şöyle örnek vermek gerekirse Amerika'da Ohio Eyaletinde Kettering ilçesi eğitim bölgesinde 1 anaokulu, 8 ilkokul, 2 ortaokul ve 1 lise varken (Kettering City School District, Ohio, 2020); Türkiye'de Amasya ilinde il milli eğitim müdürlüğüne bağlı 12 okul öncesi, 112 ilkokul, 95 ortaokul, 58 lise olduğu (Amasya İl Milli Eğitim Müdürlügü, 2020); Aydın İncirliova'da ilçe milli eğitim müdürlüğüne bağlı 3 anaokulu, 15 ilkokul, 10 ortaokul ve 5 lise bulunmaktadır (İncirliova İlçe Milli Eğitim Müdürlüğü, 2020). İl ve ilçe milli eğitim müdürlerinin sorumluluk alanlarının fazla olması yönetsel pek çok handikapı da beraberinde getirmektedir. Bunlar arasında kontrol, denetleme, bilgi akışı, öğretmenleri tanıma, öğrenci, veli, öğretmen ve yöneticilerle geçirilen zamanın kısıtlı olması, sorun çözme, mali kaynakların aktarımında sıkıntılar vb. şeklinde sayılabilir ve bunlar araştırma konusu olabilir.

Yurt dışında milli eğitim müdürleri ile ilgili çalışılan konular arasında özellikle zenci milli eğitim müdürleri, milli eğitim müdürlerinin rol ve sorumlulukları, sosyo-ekonomik düzeyi düşük bölgelerde 
görevli milli eğitim müdürleri, milli eğitim müdürlerinin öğretimsel liderlik rolleri, iletişim uzmanı olarak milli eğitim müdürleri, kadın milli eğitim müdürleri gibi çeşitli konularda nitel, nicel, alan taraması türlerinde sayısız araştırma bulunmaktadır (Björk, 2001; Björk, Kowalski ve Browne-Ferrigno, 2014; Kowalski, 2001; Kowalski vd. 2011 vb. gibi). Türkiye'de yapılan araştırmalar incelendiğinde milli eğitim müdürlerini içeren sınırlı sayıda araştırma olduğu tespit edilmiştir. Sümer (2007) milli eğitim müdürlerinin tükenmişlik düzeyini tespit etmeye dönük çalısmalar yapmıştır. Arslan ve Atasayar (2008) ise milli eğitim müdürlerinin yerelleşme konusundaki görüşlerini tespit etmeye yönelik bir araştırma yapmışlardır. Yahşi (2018) tarafından il milli eğitim müdürlerinin kariyer evresindeki ilk beş yılda yaşadıkları sorunlar araştırılmıştır. Çalışkan (2017) ise milli eğitim müdürlerinin toplantı yönetim becerilerini okul yöneticilerine sorarak tespit etmiştir. Dak (2019) ise milli eğitim müdürlerinin algılarına göre kadın yöneticilerin liderlik davranışları ve öğretmenlerin stres düzeylerini araştırmıştır. Araştırmacı tarafından yapılan bu çalışmada yer alan konuda ise henüz herhangi bir araştırmaya rastlanılamamıştır. Yapılan bu araştırma ile taşra teşkilatının yöneticileri olan milli eğitim müdürlerinin rollerinin ve görevlerinin çerçevesinin çizilmesi ile ilgili ilk çalışma olacağından önem arz etmektedir. Taşra eğitim sisteminin takım liderleri olan milli eğitim müdürlerine de yaptıkları çalışmalardaki rollerinin açık bir şekilde gösterilmesi bakımından önem arz etmektedir. Kısacası öğretmen adaylarının görüşlerinin alındığı, milli eğitim müdürlerinin rol ve sorumluluklarının doğrudan yer aldığı ne nicel ne nitel ne de karma yöntemle yapılan bir çalışma henüz bulunamamıştır. $\mathrm{Bu}$ sebeple gelecekte araştırma yapacak bireyler milli eğitim müdürlerinin rol türlerini, geliştirecekleri ölçeklerle test ederek, Türkiye'de görev yapan milli eğitim müdürlerinin hangi rolleri üstlendiklerini araştırabilirler. Milli eğitim müdürlerinin liderlik türlerinin tespit edilebileceği bir araştırma nitel, nicel veya karma yöntemle yapılarak ortaya çıkarılabilir. Benzer araştırma yurt dışındaki son sınıf öğretmen adayları ile yapılarak sonuçlar karşılaştırılabilir. Bazı sorular değiştirilerek milli eğitim müdürlerinin nasıl olduğu ve nasıl olması gerektiği öğretmen ve yöneticilere sorularak benzer araştırmalar yapilabilir.

Araştırmanın sonucuna göre milli eğitim müdürlerini yüz yüze görmeyen öğrencilerin olduğu tespit edilmiştir. Eğitim fakülteleri milli eğitim müdürlükleri ile anlaşıp, özel günler planlayarak milli eğitim müdürlerini eğitim fakültesi öğrencileri ile buluşturabilirler. Araştırmada milli eğitim müdürlerinin yüksek lisans ve doktora öğrenimli olması gerektiği öğrenciler tarafindan özellikle ifade edilmiştir. Bilginin, yeniliğin ve değişimin bu kadar önemli olduğu çağımızda halen lisansüstü öğrenim düzeyinde olmayan il ve ilçe milli eğitim müdürlerinin olması düşündürücüdür. Milli Eğitim Bakanlı̆̆ının, milli eğitim müdürü atamalarında lisansüstü öğrenim görmüş olmak şartını gerekli yasal metinlere yerleştirmesi bu araştırma sonucuna göre önerilebilir. Milli eğitim müdürlerinin iletişim ve etik özelliklerinin artırllmasına yönelik üniversitelerle işbirliği içerisinde uzaktan veya yüz yüze iletişim ve etik eğitimleri verilmesi önerilebilir. Ayrıca etik özelliklerden ortaya çıkan diğer bir sonuç ise milli eğitim müdürlerinin siyasetten uzak durmaları, siyaset yapmamalarıdır. Eğitim işiyle ilgilenen yöneticilerin her görüşe eşit mesafede olması işlerini daha başarılı yapmalarında ve çevrelerindeki bireylerde güven oluşturmalarında önemli olduğu söylenebilir. İletişimle ilgili özellikleriyle ilgili ise düzgün diksiyon, etkili konuşma, Türkçe’yi güzel konuşma özellikle vurgulanmıştır. $\mathrm{O}$ halde milli eğitim müdürlerinin bu becerilerini geliştirmesi yerinde olacaktır. Milli Eğitim Bakanlığı milli eğitim müdürü seçerken ve atarken bu hususa özellikle dikkat etmesinin yerinde bir uygulama olacağı söylenebilir. Öğrencilerin yarıdan fazlasının milli eğitim müdürü olmayı istemeleri ile ilgili görüşlerinin ve hayallerinin olması sevindiricidir. Çünkü başarı önce hayal kurmakla, ardındansa bu hayalleri gerçekleştirmek için çalışmakla yerine getirilebilir. Öğrencilerin idealist olmaları Türk eğitim sistemi açısından sevindirici bir unsur olarak ifade edilebilir. Milli eğitim müdürü olmayı istemeyen öğrencilerin görüşleri de anlamlıdır. Çünkü öğrencilerin iyi öğretmen olmayı istemeleri ve bazı becerilerin kendinde olmadığını bilerek öz değerlendirme yapmaları, geleceğin öğretmenlerinin gerçekçi ve dürüst bir yaklaşım içinde olmalarının gelişim için önemli bir unsur olduğu söylenebilir.

\section{Etik Kurul İzni ve Etik Beyanı}

Araştırma, Aydın Adnan Menderes Üniversitesi Eğitim Fakültesinin 07.05.2020 tarih ve 2020/06 sayll Eğitim Araştırmalanı Etik Kurulu toplantısında etik açıdan uygun görülmüştür. "Milli Ë̆gitim Bakanluğ Taşra Teşkilatı Yöneticileri: Milli Eğitim Müdürleri Üz̧erine Nitel Bir Çalışma" başılılı çalışmanın yazım sürecinde bilimsel, etik ve alıntı kurallarına uyulmuş; toplanan veriler üzerinde herhangi bir tahrifat yapılmamıs ve bu çalışma herhangi başka bir akademik yayın ortamına değerlendirme için gönderilmemiştir. 


\section{Kaynaklar}

Amasya İl Milli Eğitim Müdürlüğü. (2020). https://amasya.meb.gov.tr/. Erişim Tarihi: 01.07.2020.

Amerika Ohio Kettering Şehri Okul Eğitim Bölgesi- Kettering City School District. (2020). https://www.ketteringschools.org/. Erişim Tarihi: 01.07.2020.

Arslan, M. M. ve Atasayar, H. H. (2008). Milli Eğitim Bakanlığı taşra örgütü yöneticilerinin yerelleşme konusundaki görüşleri. Ankara Üniversitesi Eğitim Bilimleri Fakültesi Dergisi, 41(2), 59-79.

Axley, S. R. (1996). Communication at work: Management and the communication-intensive organization. Westport: Quorum.

Aydın İncirliova Milli Eğitim Müdürlüğü. (2020). http://incirliova.meb.gov.tr/. Erişim Tarihi: 01.07.2020.

Başaran, E. (1988). Ë̆itim yönetimi. Ankara: Umut.

Başaran, E. (1991). Örgütsel davramıs. Ankara: Gül.

Björk, L. G. \& Gurley, D. K. (2005). Superintendent as educational statesman and political strategist. L. G. Björk \& T. Kowalski (Edts.), The contemporary superintendent: Preparation, practice, and development (pp.163-185). Thousand Oaks: Corwin.

Björk, L. G., Kowalski, T. J., \& Browne-Ferrigno, T. (2014). The school district superintendent in the United States of America. A. E. Nir (Edt.). The educational superintendent: Between trust and regulation. An international perspective (pp.17-38). Hauppauge: Nova.

Björk, L. G. (2001). The role of the central office in decentralization. T. J. Kowalski \& G. Perreault (Edts.). 21st century challenges for school administrators (pp. 286-309). Lanham: Scarecrow Press.

Björk, L., \& Lindle, J. C. (2001). Superintendents and interest groups. Educational Policy, 15(1), 76-91.

Browne-Ferrigno, T., \& Glass, T. E. (2005). Superintendent as organizational manager. L. G. Björk and T. J. Kowalski (Edts.). The contemporary superintendent: Preparation, practice, and development (pp. 137-161). Thousand Oaks: Corwin.

Cafaoğlu, Z. (1996). Eğitimde toplam kalite yönetimi. İstanbul: Avni Akyol Ümit Kültür Vakf1 Yayınları.

Callahan, R. E. (1962). Education and the cult of efficiency: A study of the social forces that have shaped the administration of public schools. Chicago: University of Chicago Press.

Callahan, R. E. (1966). The superintendent of schools: A bistorical analysis (Unpublished manuscript). Graduate Institute of Education, Washington University, St. Louis.

Cappella, J. N. (1987). Interpersonal communication: Definitions and fundamental questions. C. R. Berger \& S. H. Chaffee (Edts.). Handbook of communication science (pp. 184-238). Newbury Park: Sage.

Conrad, C. (1994). Strategic organizational communication: Toward the twenty-first century. Fort Worth: Harcourt Brace College.

Creswell, J. W. (2016). Qualitative inquiry and research design choosing among five approaches. (Çev: M. Butun \& S. B. Demir). Ankara: Siyasal.

Cronin, J. M. (1973). The control of urban schools: Perspective on the power of educational reformers. New York: Free Press.

Cuban, L. (1976). The urban school superintendent: A century and a half of change. Bloomington: Phi Delta Kappa Educational Foundation.

Cumhurbaşkanlığı Teşkilatı Hakkında Cumhurbaşkanlığı Kararnamesi (Cumhurbaşkanlığı 1 nolu Kararnamesi). (2018). https://www.mevzuat.gov.tr/MevzuatMetin/19.5.1.pdf. Tarih ve sayı: 10.7.2018 - 30474.

Çalışkan, A. (2017). Okul yöneticilerinin algzlarnna göre ilçe milli eğitim müdürlerinin toplantı yönetimi becerileri (Yüksek Lisans Tezi). İstanbul Sabahattin Zaim Üniversitesi, İstanbul.

Dak, G. (2019). Milli Ë̆itim Bakanlĭg taşra örgütündeki üst düzey yöneticilerin algzlarna göre kadn yöneticilerin liderlik davranıslar ve ögretmenlerin örgütsel stres düzeyleri (Yüksek Lisans Tezi). Çanakkale Onsekiz Mart Üniversitesi, Canakkale.

Devlet Memurlar1 Kanunu. (1965). Tarih ve Sayl: $14.07 .1965 \quad$ ve 657. https://www.mevzuat.gov.tr/MevzuatMetin/1.5.657.pdf. Erişim Tarihi: 08.02.2020.

Edmonson, A. C. (2012). Teaming: How organizations learn, innovate, and compete in the knowledge economy. San Francisco: Jossey-Bass.

Ersoy, A. F. (2019). Fenomenoloji. A. Saban ve A. Ersoy (Edts.). Eğitimde nitel araştrma desenleri. Ankara: Anı.

Fusarelli, B. C., \& Fusarelli, L. D. (2005). Reconceptualizing the superintendency: Superintendents as social scientists and social activists. L. G. Björk \& T. J. Kowalski (Edts.). The contemporary superintendent: Preparation, practice, and development (pp. 187-206). Thousand Oaks: Corwin.

Glass, G. V. (2008). Fertilizers, pills, and magnetic strips: The fate of public education in America. Charlotte: Information Age Publishing.

Glass, T. E., Björk, L. G., \& Brunner, C. C. (2000). The study of the American superintendency 2000: A look at the superintendent in the new millennium. Arlington: American Association of School Administrators.

Goldring, E., \& Greenfield, W. (2002). Understanding the evolving concept of leadership in education: Roles, expectations, and dilemmas. J. Murphy (Edt.). The educational leadership challenge: Redefining leadership for the 21st Century (pp. 1-19). Chicago: University of Chicago Press

Grunig, J. E. (1989). Symmetrical presuppositions as a framework for public relations theory. C. H. Botan (Edt.). Public relations theory (pp. 17-44). Hillsdale: Erlbaum. 
Grunig, J. E., \& Huang, Y. H. (2000). Antecedents of relationships and outcomes. J. Ledingham \& S. Bruning (Edts.). Public relations as relationship management (pp. 23-54). Mahwah: Erlbaum.

Heckman, P. E. (1993). School restructuring in practice: Reckoning with the culture of school. International Journal of Educational Reform, 2(3), 263-272.

Hirokawa, R. Y. (1990). The role of communication in group decisionmaking efficacy: A task contingency perspective. International Journal of Theory, Investigation, and Application, 21(2), 190-204.

Kaya, Y. K. (1999). Eğitim yönetimi, kuram ve Türkiye’deki uygulamalar. Ankara: Bilim .

Katzenback, J. R., \& Smith, D. K. (2004). The discipline of teams. Boston: Harvard Business School.

Kıral, B. (2015). Lise yöneticilerinin ögretmenleri güclendirmesi ve ögretmenlerin kayntsız̆hk (sinizm) davranıs̆ ile ilişkisi (Doktora tezi). Ankara Üniversitesi, Ankara.

Kıral, E. (2019). Milli Eğitim Bakanlı̆̆ örgütlenmesi. U. Akın (Edt). Türk eğitim sistemi ve okul yönetimi. Ankara: PegemAkademi.

Kirst, M. W., \& Wirt, F. M. (2009). The political dynamics of American education. Berkeley: McCutchan.

Kowalski, T. J. (1999). The school superintendent: Theory, practice, and cases. Upper Saddle River: Merrill, Prentice Hall.

Kowalski, T. J. (2000). Cultural change paradigms and administrator communication. Contemporary Education, $71(2), 5-$ 10.

Kowalski, T. J. (2001). The future of local school governance: Implications for board members and superintendents. C. C. Brunner \& L. G. Björk (Edts.). The new superintendency (pp. 183-201). Oxford: JAI Press.

Kowalski, T. J. (2003). Contemporary school district administration: An introduction. Boston: Allyn \& Bacon.

Kowalski, T. J. (2005). Evolution of the school superintendent as communicator. Communication Education, 54(2), 101-117.

Kowalski, T. J., \& Björk, L. G. (2005). Role expectations of district superintendents: Implications for deregulating preparation and licensing. Journal of Thought, 40(2), 73-96.

Kowalski, T. J., \& Glass, T. E. (2002). Preparing superintendents in the 21 st century. B. S. Cooper \& L. D. Fusarelli (Edts.). The promises and perils facing today's school superintendent (pp. 41-60). Lanham: Scarecrow Education.

Kowalski, T. J., McCord, R. S., Petersen, G. J., Young, I. P., \& Ellerson, N. M. (2011). The American school superintendent: 2010 decennial study. Lanham: Rowan \& Littlefield Education.

Kowalski, T. J., Peterson, G. J., \& Fusarelli, L. D. (2007). Effective communication for school administrators: A necessity in an information age. Lanham: Rowan \& Littlefield.

Lambkin, M. L. (2006). Challenges and changes faced by rural superintendents. The Rural Educator, 28(2), 17-24.

Lencioni, P. (2002). The five dysfunctions of a team: A leadership fable. San Francisco: Jossey-Bass

Levin, H. M. (1999). The public-private nexus in education. The American Behavioral Scientist, 43(1), 124-137.

Littlejohn, S. W. (1992). Theories of human communication. Belmont: Wadsworth.

Maarif Teşkilatına Dair Kanun. (1926). Tarih ve Sayı: 22.03 .1926 ve 789. https://www.tbmm.gov.tr/tutanaklar/kanunlar kararlar/kanuntbmmc004/ka nuntbmmc004/kanuntbmmc00400789.pdf. Erişim Tarihi: 08.02.2020.

Miles, M. B. \& Huberman, A. M. (1994). Qualitative data analysis. Thousand Oaks: Sage.

Millar, F. E., \& Rogers, L. E. (1976). A relational approach to interpersonal communication. G. Miller (Edt.), Explorations in Interpersonal Communication (pp. 87-103). Newbury Park: Sage.

Millî Eğitim Bakanlığı'nın Teşkilat ve Görevleri Hakkında Kanun Hükmünde Kararname. (2011). Tarih ve Sayı: 14.09.2011 ve 652. https://www.resmigazete.gov.tr/eskiler/2011/09/20110914- 1.htm.Erişim Tarihi: 08.02.2020.

Millî Eğitim Bakanlığı Personelinin Görevde Yükselme, Unvan Değişikliği ve Yer Değiştirme Suretiyle Atanması Hakkında Yönetmelik. (2013). Tarih ve Sayl: 12.10.2013 ve 28793. https://www.resmigazete.gov.tr/eskiler/2013/10/20131012-46.htm. Erişim Tarihi: $\quad$ 08.02.2020.

Milli Eğitim Bakanlığ1 Yönetici Atama, Değerlendirme, Görevde Yükselme ve Yer Değiștirme Yönetmeliği. (1999).

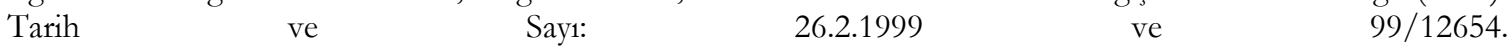
https://www.mevzuat.gov.tr/mevzuat?MevzuatNo=18945\&MevzuatTur=7\&MevzuatT ertip=5. Erişim Tarihi: 08.02.2020.

Milli Eğitim Bakanlığ1 Yönetici Atama ve Görevde Yükselme Yönetmeliği. (2003). Tarih ve Sayı: 11.6.2003 ve 25135. https://www.resmigazete.gov.tr/eskiler/2003/06/20030611.htm\#9. Erişim Tarihi: $\quad$ 08.02.2020.

Millî Eğitim Bakanlı̆̆ı Personelinin Görevde Yükselme, Unvan Değişikliği ve Yer Değiştirme Suretiyle Atanması Hakkında Yönetmelikte Değişiklik Yapılmasına Dair Yönetmelik. (2016). Tarih ve Sayı: 13.01 .2016 ve 29592. https://www.resmigazete.gov.tr/eskiler/2016/01//20160113- 3.htm. Erişim Tarihi: 08.02.2020.

Millî Eğitim Bakanlığ1 Personelinin Görevde Yükselme, Unvan Değişikliği ve Yer Değiştirme Suretiyle Atanması Hakkında Yönetmelikte Değişiklik Yapılmasına Dair Yönetmelik. (2018). Tarih ve Sayı: 13.01.2018 ve 30300. https://www.resmigazete.gov.tr/eskiler/2018/01/20180113- 17.htm. Erişim Tarihi: 08.02.2020.

Millî Eğitim Bakanlı̆̆1 Personelinin Görevde Yükselme, Unvan Değişikliği ve Yer Değiştirme Suretiyle Atanmas1 Hakkında Yönetmelikte Değişiklik Yapılmasına Dair Yönetmelik. (2020). Tarih ve Sayı: 19.07 .2020 ve 31190. https://www.resmigazete.gov.tr/eskiler/2020/07/20200719-6.htm Erişim tarihi: 02.11.2020. 
Millî Eğitim Bakanlığı Personelinin Görevde Yükselme, Unvan Değişikliği ve Yer Değiştirme Suretiyle Atanması Hakkında Yönetmelikte Değişiklik Yapılmasına Dair Yönetmelik. (2020). Tarih ve Sayı: 18.07.2020 ve

31189. https://www.resmigazete.gov.tr/eskiler/2020/07/20200718-2.htm. Erişim tarihi: 02.11.2020.

Owens, E. R., \& Valesky, R. E. (2015). Organizational behavior in education: Leadership and school reform. Boston: Pearson.

Patton, B. R., \& Downs, T. M. (2003). Decision-making group interaction. Boston: Allyn \& Bacon.

Reitz, H. J. (1987). Behavior in organizations. Homewood: Irwin

Starratt, R. K. (1991). Building an ethical school: A theory for practice in educational leadership. Educational Administration Quarterly, 27(2), 185-202.

Schlechty, P. C. (1997). Inventing better schools: An action plan for educational reform. San Francisco: Jossey- Bass.

Sergiovanni, T. J. (2006). The principalship: A reflective practice perspective. Boston: Allyn and Bacon

Sümer, S. (2007). Milli Eğgitim Bakanlĭğ taşra teşkilatı yöneticilerinin tükenmişslik düreyi (Yüksek Lisans Tezi). Yıldız Teknik Üniversitesi, İstanbul.

Thayer, L. O. (1961). Administrative communication. Homewood: Irwin.

Ubben, G., Hughes, L. \& Norris, C. (2004). The principal: Creative leadership for effective schools. Boston: Allyn \& Bacon.

Wirt, F., \& Kirst, M. (2001). The political dynamics of American education. Berkeley: McCutchan.

Van Til, W. (1971). Prologue: Is progressive education obsolete? W. Van Til (Edt.). Curriculum: Quest for relevance (pp. 9-17). Boston: Houghton-Mifflin.

Yahşi, Ö. (2018). İlçe milli eğitim müdürlerinin kariyer giris evresinde yaşadıklar sorunlar ve çözüm yollar (Doktora Tezi). Marmara Üniversitesi ve İstanbul Sabahattin Zaim Üniversitesi Ortak Doktora Programı, İstanbul.

\section{EXTENDED ABSTRACT}

Provincial and district superintendents work as representatives of the Ministry of National Education. They are tasked with supervising the functioning of educational institutions in the provinces and districts, checking the compliance of their activities with the policies established by the ministry, and making these organizations necessary directions for them to work towards the goals of the ministry (Kaya, 1999). According to this article, the Ministry is authorized to establish a provincial organization; a national education superintendent will be established in each province and district. It is stated that the district national education superintendents will be responsible to the provincial superintendents of national education while performing their duties and services. The research was carried out in order to determine the teacher candidates' national education superintendents, what their duties and roles are and how they should be. In line with this main purpose, answers to the following sub-problems were sought.

Pre-service teachers;

1. What are the views of the superintendents of national education about who they are, their duties and what they look like?

2. What are the views of the national education superintendents about their characteristics?

3. What are the views of the superintendents of the national education regarding their characteristics?

4. What are the views of the superintendents of the national education regarding their roles and what their roles look like?

5. What are their views on whether they want to become the superintendents of national education in the future?

The research is conducted qualitative research; It was carried out in the phenomenology pattern (Creswell, 2016). The study group of the research consists of 106 volunteer 4th year students studying at the education faculty of a state university in second term of 2019-2020 academic year. The students participating in the study were selected from the purposeful sampling methods using the criterion sampling method. The criteria in this research are that the students are prospective teacher candidates studying in the 4th grade selected from different branches. Before starting the research, "official written permission and ethics committee permission" was obtained from the education faculty of the relevant university and the research was started.

In the research, the individuals whose national superintendents assumed managerial duties, carrying out works related to teachers and students, working towards educational institutions, monitoring and evaluating were evaluated in categories. When asked about the characteristics of the national education superintendents, four basic categories were created in line with the answers given by the students. These are educational, personality, communicative and ethical characteristics. The most desired of these categories is that the national education superintendents should be trained at postgraduate level (master and $\mathrm{PhD}$ ). It was also emphasized that they should be exemplary in terms of personality, open to innovation and change. 
KIRAL

It was also stated that the superintendents of national education do not do politics and that they are in justice. Communication skills are one of the most repeated expressions of speaking properly and effectively. When asked which roles of national education superintendents are, it is stated that they have roles such as manager, parent, teacher, supervisor. In the future role of superintendents of national education will research the types of individuals, to test the scale to be developed, may investigate what roles they assumed the acting superintendent of national education in Turkey. A research in which the types of leadership of the national education superintendents can be determined can be revealed through a qualitative, quantitative or mixed method. Similar research can be done with final year prospective teachers in different countries 4th grade students and the results can be compared. Similar research can be done by asking teachers and administrators how national education principals are. According to the results of the research, it was determined that there are students who do not see the national education superintendents face to face. Education faculties can get together with the education faculty students with special days with superintendents. In the research, it was specifically stated by the students that the national education principals should have master and $\mathrm{PhD}$ education. 